Max-Planck-Institut für demografische Forschung

Max Planck Institute for Demographic Research

Konrad-Zuse-Strasse 1 - D-18057 Rostock - GERMANY

Tel +49 (0) 3812081 - 0; Fax +49 (0) 3812081 - 202;

http://www.demogr.mpg.de

MPIDR WORKING PAPER WP 2010-036

DECEMBER 2010

\title{
Living arrangements and household formation in the crucible of social change: Rostock 1867-1900
}

Mikołaj Szołtysek (szoltysek@demogr.mpg.de)

Siegfried Gruber (gruber@demogr.mpg.de)

Barbara Zuber-Goldstein (zuber@demogr.mpg.de)

Rembrandt Scholz (scholz@demogr.mpg.de)

(C) Copyright is held by the authors.

Working papers of the Max Planck Institute for Demographic Research receive only limited review. Views or opinions expressed in working papers are attributable to the authors and do not necessarily reflect those of the Institute. 


\section{Szołtysek, S. Gruber, B. Zuber-Goldstein, R. Scholz ${ }^{*}$}

\section{Living arrangements and household formation in the crucible of social change: Rostock 1867-1900}

\section{Introduction}

Over the last half century, the relationship between industrialization, urbanization, and demographic change has attracted an enormous amount of attention among historical demographers, as well as among family and urban historians. In the works of the first generation of scholars, special consideration was given to family and domestic groups, as they were seen as primary arenas in which many of the relationships between individuals, institutions, and socioeconomic change were acted out (Hareven 2000, 321). Applying structural-functionalist theories, family historians of the 1970s and 1980s came to challenge many fundamental generalizations about the historical impact of industrialization on households and families. Yet many questions were left unanswered (Kertzer and Schiaffino 1983; Arcury 1990). While over subsequent decades there was continued interest in studying the relationship between historical industrial change and demographic change, the discussion of the impact of the former on the most basic of social institutions - the household and the family - has since faded. This research reintroduces to the historical-demographic literature the problem of the relationship between a set of processes generally labeled as "industrialization" and family change. Employing a variety of quantitative methodologies, we examine the impact of developing urban industrial life on the family system of the industrialising city of Rostock, with the goal of capturing long-term structural developments in nuptiality, residence patterns, and household formation rules; as revealed in the city's two censuses of 1867 and 1900. This newly available material provides new empirical insights, and may contribute to the further construction of theories regarding the interplay between processes of social change and family change in the past.

The paper is organized as follows. We open with a brief review of older and newer perspectives on changes in the urban family structure associated with modernization and industrialization. This is followed by a discussion of the censal basis of our research, and by

\footnotetext{
* Laboratory of Historical Demography, Max Planck Institute for Demographic Research Rostock, Germany. Address all communication to: $\underline{\text { Szoltysek@ demogr.mpg.de or Gruber@ demogr.mpg.de. }}$
} 
some methodological considerations. The first section concludes with an assessment of basic demographic trends and the development of urban industrial life in Rostock during the $19^{\text {th }}$ century. In the main body of the paper that follows, we examine long-term changes in the family system in Rostock between 1867 and 1900, including patterns of marriage and household formation and headship, as well as household structure and composition. We then supplement this more conventional approach with an investigation of changes in the intergenerational bonds and co-residence patterns of the elderly. The gender, occupational, and spatial differentials of the processes involved will also be discussed, as will the role played by the migration characteristics of individuals in their residence and life-course patterns. We close with a general discussion and conclusion.

\section{Older and newer perspectives on the urban family structure}

A striking diversity of opinions still seems to exist among scholars regarding the links between "modernization" processes and the family structure. Conventional theoretical wisdom, from F. Le Play up to the early 1970s, held that industrialization resulted in the disintegration of the family group into smaller units of nuclear families. The nuclear family was thought to be best adapted to meet the demands imposed by the high rates of social and geographical mobility of individuals that was typical of the industrial system. Accordingly, it was presumed that nuclear families would do better than extended families in achieving the social and economic goals that characterize industrial society, and that individuals living in nuclear family units would be better equipped to reach higher positions in life (e.g., Parsons \& Bales 1955; Goode 1963, 1966).

Later research undermined the hypothesis of the progressive nuclearization of the family by suggesting that major shifts over the past centuries, such as industrialization and urbanization, have had a little or no effect on the structure of the family and the household, at least in some regions of Europe (Laslett 1972). Some scholars went so far as to reverse the usual structural-functional reasoning and argue that particular developments in the West were attributable to distinctive family and demographic arrangements. From that perspective, the nuclear family, along with the Western European marriage pattern, were seen as being among the necessary preconditions for modernization, industrialization, and economic growth (Macfarlane 1987; Laslett 1983; recently Hartmann 2004; De Moor and Van Zanden 2010).

By contrast, other researchers saw extended family arrangements as a positive and functional adaptation to industrial life. Substantial evidence was provided demonstrating that 
the harsh economic conditions of early industrial capitalism strengthened the interdependence of family members, and sometimes led to a high frequency of complex households (Anderson 1971; Hareven 1978, 1982; also Wrigley 1977, 82; recently King and Timmins 2001, 275 276).

Other perspectives exist, however. Kertzer, for example, argued that only a small degree of change in the persistent attachment to living in complex domestic units occurred in central Italy, despite the critical transformation of socioeconomic and occupational structures (Kertzer 1984). Janssens' study of the Dutch town of Tilburg took roughly the same view, describing a striking continuity in the overall pattern of extended living arrangements, despite the profound process of social change surrounding the town's families (Janssens 1993). The results of these and other studies may be viewed as evidence that the effects of industrialization on households and families could have differed from community to community. The nature of the pre-existing family system, the characteristics of the industry and its technology, the demographic processes in the community, the relative poverty of the workers and the availability of housing, along with the socio-cultural characteristics and type of migratory population movements involved, may all affect the nature and direction of change in a family system in a variety of ways (Kertzer and Schiaffino 1983; Arcury 1990; Bourdieu, Kesztenbaum and Postel-Vinay 2010; King and Timmins 2001, 244-278; Bourdelais 2000; Oris 2003). A model of social change in which family change is not directly and immediately linked to structural social transformation seems equally convincing. A "cultural lag" is likely to exist between family systems and socio-structural developments (Janssens 1993; also Scott \& Tilly 1975; Medick 1981).

\section{Data and methodology}

This study uses the rich historical census microdata that was gathered for the urban community of Rostock in 1867 and $1900^{1}$. The 1867 census was taken in the Grand Duchy of Mecklenburg-Strelitz and the Grand Duchy of Mecklenburg-Schwerin on the occasion of these territories' accession to the North German Confederation and the German Customs Union in 1867/68. The 1900 census of the Grand Duchy of Mecklenburg-Schwerin was conducted as part of an all-encompassing enumeration of the population of the German

\footnotetext{
${ }^{1}$ In our earlier study, we used the 1819 census of Mecklenburg (one of the oldest surviving individual-level data population censuses in Germany). However, this census count poses several methodological problems that hinder its exploitation in the present study (see Gruber et.al. 2010; also Szołtysek et.al. 2009).
} 
Empire in 1900. The two censuses used modern refined population-counting methods, which were first implemented in Germany in the 1860s. These censuses provide a wealth of information, such as an individual's name and surname, sex, year of birth, place of birth (only for 1900), relationship to the household head, occupational and marital status, as well as religion; and can thus be successfully used to conduct a structural analysis of the family system. Even though these data span significant distances of time and originate from different historical contexts, they provide closely comparable information on living arrangements ${ }^{2}$. In this paper, we use a complete censal collection from 1867, together with a 75 percent random sample from the 1900 census. All in all, we are dealing with 6,698 households from the first enumeration and 11,054 domestic units from the second one, with an overall population of 69,514 individuals $^{3}$.

We conceptualize the relationship between industrialization and the family domain as the former having an effect on the entirety, or on some constitutive parts, of the prevailing family system. The concept of the family system has been used frequently in studies of historical demographic structures, where it has been applied to denote a wide variety of circumstances (Laslett, 1983; Todd 1985; Wall 1991, 623; Berquo \& Xenos 1992). In line with Polla (2006), we define it as "an entity that comprises the household and marriage arrangements typical of a certain population at a certain time and all connected phenomena." Defined in this way, a family system is a social institution that changes with time, and its development depends on the combined effects of numerous external factors, including economic, social, and ecological influences (Polla 2006, 28-29) ${ }^{4}$.

We argue that the change that occurs in a family system should be investigated through a simultaneous observation of the structural quantitative developments in all its

\footnotetext{
${ }^{2}$ According to the census definition of household at that time, a group of people was considered to be a coresident domestic group if they were living together on the basis of shared resources. Not only biological members of the family and other related persons were included in this category, but also servants, boarders, and lodgers (Rothenbacher 2002, 278; for explicit definition see SDRNF-32; 1888, page 8*).

${ }^{3}$ In the following analysis the military population is excluded. The sample of 1900 includes only about 10 percent of the military population of that year. These are mostly officers and the inmates of the military hospital, while the inmates of the military barracks are missing. An analysis would therefore be heavily biased, also in comparison to 1867. Second, the soldiers were put into private households (where they lived as boarders) until 1890, when they began living in military barracks (Schröder 2010, 145). Our analysis focuses on family households only, so it excludes institutional households in which the military population were living in 1900.

${ }^{4}$ Oris and Ochiai $(2002,36)$ proposed a more general definition of the family system as "a cultural construction under economic and demographic constraints."
} 
domains, including marital behavior, household structure and composition, the life-course transitions of individuals, the living arrangements of the aged, and the service system (i.e., the existence of a specific pattern of life-cycle service). These aspects of a family system are identical to the domains used in our previous study, and the detailed descriptions and rationale for each of them are documented there (Szołtysek et.al. 2009, 13-17).

To achieve our aims, the analysis of the family system components must be limited to the investigation of their most important features. It should be emphasized, however, that each of these aspects could become the subject of a separate in-depth study. This also means that we can devote only a relatively small amount of space to comparing familial developments in Rostock with the situation in other urban sites of the German-speaking area of the same period, and to making wider European comparisons. It is, in any case, difficult to make such comparisons. The co-residence patterns in historical Germany have thus far been either unexplored, or mentioned only in passing in the literature (Rosenbaum 1996; WeberKellermann 1982; Lee 1981) ${ }^{5}$. Most of the scholarly works on the relationship between industrialization and demographics have focused on individual aspects of demographic change, often without addressing the problem of changes occurring in living arrangements and household formation patterns (e.g., Oris and Alter 2001; Oris 2000; Brändström, Sundin, \& Tedebrand 2000; Lee 1998, 1999, 2005; Lee and Marschalck 2000, 2002; for exceptions, see Kertzer and Schiaffino 1983; Janssens 1993; Alter 1996; Hareven 2000; Arcury 1990). Here, we have decided to take a more holistic approach, pooling together various aspects of family change, and leaving other domains of demographic transformation for later exploration.

The approach taken here measures co-residence at the level of population, households, but also individuals. Looking at living arrangements from different perspectives allows us to partly overcome a substantial criticism of the household-level variables expressed in family demographic literature (Ruggles 1987, 1990, 2009; King and Preston 1990; King 1990). Accordingly, in this study we supplement a more conventional approach to studying living arrangements by treating co-residence with relatives of a particular type as a key characteristic of individuals, who are then classified based on the presence or absence of different types of ties to others.

\footnotetext{
5 Jackson's study of the city of Duisburg in western Germany, along with Hubbard's analysis of Graz in Austria, remain the major reference points for our study (Jackson 1997; Hubbard 1976). In the second half of the $19^{\text {th }}$ century, Duisburg was dramatically affected by the arrival of heavy industry to the Ruhr valley; Graz can be characterized as a city of engineering, civil servants, and pensioners (Hubbard 1976, 286).
} 


\section{Basic demographic trends and the development of industrial life in Rostock}

Rostock was the biggest city of the Grand Duchy of Mecklenburg-Schwerin, and was home to around five percent of its entire population. During the $19^{\text {th }}$ century, crude birth rates hovered at around 30 in the city, and crude death rates were between 20 and 25 . These rates provided for a natural increase in the population, which was also accompanied by a positive migration balance. These two trends together produced population growth of 1.25 percent per annum. As a consequence, the population of Rostock grew steadily, from 12,585 in 1800 to 28,511 in 1867; and, finally, to 54,735 in 1900 . Up to about 1872 , immigration was more important for population growth than natural increase, while thereafter natural increase became the leading impetus $^{6}$. In 1900 a majority (55.9 percent) of the Rostock population had been born outside of the city. The proportion was 70 percent and more among the groups of working ages, while relatively few children were born outside of the city. These proportions were clearly higher than in 1819, when only 39.2 percent of the population were immigrants to the city (unfortunately, the census of 1867 does not provide the place of birth) ${ }^{7}$.

The relatively young and growing population of Rostock can be represented graphically in the form of two superimposed pyramids (referring to two censal years), both of which are wider at the base, and which grow narrower as age increases (Figure 1) ${ }^{8}$. In both populations, however, the effect of immigration by young adults was causing a bulge at around ages 20 to 25 (slightly earlier in 1867).

\section{Figure 1: somewhere here}

\footnotetext{
${ }^{6}$ This feature was only partly shared with the Mecklenburg hinterland. The province experienced a dynamic population development, from 395,383 inhabitants in 1819 , to 625,045 in 1905 . However, while the population grew at an annual rate of 1.15 percent for the first half of the century (1819-1850), the growth rate for the rest of the 19th century was only 0.68 percent (Haak 1977, 932; see also Constantine 2007, 7-8; Oeppen and Toch 2010). The population of Rostock was smaller and grew at a slower pace than in the major port cities of northern Germany, like Hamburg or Bremen (Lee and Marschalck 2002, 255-256). Duisburg grew from having a population of around 7,000 in 1831 to more than 92,000 in 1900 (Jackson 1997, 7).

${ }^{7}$ In Bremen, the proportion of the in-migrant population was 36 percent in 1862, but rose to 46 percent in 1905 (Lee 1999, 442). In industrial cities like Bochum and Gelsenkirchen, almost two-thirds of the population were born outside the city in 1907, while the average for German cities with more than 100,000 inhabitants was 58 percent (Köllmann 1959, 64 ff.).

${ }^{8}$ Strong effects of age heaping cannot be seen in either of the censuses. The calculation of total modified Whipple's indices (Wtot) yielded 1.61 for men and 1.78 for women in 1819, and only 0.45 for men and 0.51 for women in 1867. The 1900 hundred census yielded even smaller values (see Spoorenberg 2007).
} 
A decomposition of the 1900 pyramid into native and immigrant populations reveals remarkable differences in the age structures of the two subsets. The ratio of the population aged $0-15$ to the total population was 53.8 percent in the native group, and only 13.2 percent among the immigrants (see also Prill 2010, 12-14) ${ }^{9}$. Women were, with shares of 50.5 percent in 1867 and 54.2 percent in 1900, in a slight majority in the city in both censuses, and these patterns have been found to hold when natives and immigrants were studied separately. A male majority occurred only among the younger age groups: up to 24 years in 1867, and up to 14 years in 1900, while the female share of the population increased with age ${ }^{10}$.

Important changes in infant mortality were taking place between the censuses, leading to an increase in life expectancy at birth of 10 years for males and 13 years for females, and indicating early signs of the demographic transition ${ }^{11}$.

Whereas in the first census the majority of population were still living in the inner city (i.e., within the city walls), by 1900 more than half of Rostock's inhabitants were occupying newly developed districts, especially in the Kröpeliner-Tor Vorstadt, where more than 40 percent of the total population lived ${ }^{12}$. Around 1900, six districts formed the city of Rostock: the Old Town, the New Town, and the four suburbs named after the four town gates (Polzin and Witt 1975, 58). Two large newly developed districts (Kröpeliner-Tor Vorstadt/KTV and Steintor Vorstadt/STV) differed substantially in terms of the socioeconomic composition of their populations: one had become a predominantly skilled and unskilled working-class area, while the other had a high concentration of white-collar professionals and people involved in trade.

Once a vital port town of the Hansa that shared a common maritime past with Hamburg, Bremen, and Lübeck, Rostock later experienced a centuries-long economic decline.

\footnotetext{
${ }^{9}$ Since the children of the immigrants to the city are treated in the census as "native-born," the actual difference between the two subpopulations should be smaller. The respective numbers in Bremen in 1905 were 48.5 percent and 10 percent (Lee and Marschalck 2000, 381).

${ }^{10}$ This is partly corroborated by the ratios of unmarried men to unmarried women in the age group 20-29. In 1900 there was a female majority within this age group of 52.2 percent, while the numbers were almost even in 1867 (women made up 49.8 percent; with soldiers excluded in both censuses).

${ }^{11}$ There was only a very minor change in life expectancy at older ages (less than one year at age 60).

12 Only 2,554 people lived in the KTV area in 1867. Thirty-three years later, the population of this district had increased to over 22,000. The substantial expansion of the city's boundaries during the 19th century was due to a large wave of construction of building stock in the western and southern suburbs between 1876 and 1914. Over 80 percent of all $(3,494)$ houses in Rostock around 1886 had a water connection, whereas nearly all new buildings in the suburbs had both a water and a gas connection (Bluhm 2005).
} 
With the advent of industrialization in Germany, Rostock was affected by the economic shift, with several promising initiatives taking root in the city in the first half of the $19^{\text {th }}$ century (the first railways in 1850; first steam engines and two banks by 1850; seven public schools by 1860 (Karge, Schmied and Münch 2004, 270-273; Mecklenburgischer Staatskalender 1830, p. 143; 1840, p. 196-197; 1850, p. 207; 1860, p. 185 and 213). The Crimean War (1853-1856) also helped the city to (albeit temporarily) strengthen its economic position through profiteering from grain shipments and transports of weapons into the war zone (Polzin and Witt 1974, 51-52; Schröder 2003, 135).

Nevertheless, Rostock never became a fully successful pioneer of industrial development, and as modernization efforts slowed around the middle of the $19^{\text {th }}$ century, the city went into a decline that was about to last for nearly four decades ${ }^{13}$. In 1853 , there were only 14 companies with more than 10 employees in the city. The overall number of employees and unspecified job-holders in Rostock's main factories fell from 357 in 1858 to 238 in 1874 (Groenke 1982, 8ff). Between 1849 and 1866, nine shipyards were founded in the city, but only one of them produced iron ships. Despite of the availability of wage workers (Schultz 1975, 166-170), there was little investment in industrial production plants. In addition, the export of goods produced in Rostock started to decline in the late 1850s, mainly due to the newly opened railway and shipping routes that connected Prussian territories with port towns in East and West. This stagnation in progress was not alleviated until 1890, when Rostock's steel shipbuilding industry reached a critical mass and became the motor that led the town into the industrialization wave of the $20^{\text {th }}$ century. At the time of the 1900 census, the shipbuilding industry was already in full swing, with the number of employees in the city's largest shipyard tripling from 500 in 1895 to 1500 in 1902 (Polzin and Witt 1974, 60). Other sectors of economy, however, continued to lag far behind ${ }^{14}$.

Many of the developments in Rostock were hampered by restrictive legislation and the persistence of "pre-modern" social, occupational, and institutional structures (Manke 2000, 210-212). While serfdom was abolished in Mecklenburg in 1819, the right of abode was not

\footnotetext{
${ }^{13}$ While rapid and steady economic and social change was occurring during the second half of the 19th century in the biggest port city of northern Germany, Hamburg (see Wischermann 2002), Bremen seem to have represented an intermediate pace of development between that of the fast-growing Hamburg and the largely stagnating Rostock (on Bremen: Lee 1999, 194-196; Lee and Marschalck 2002).

${ }^{14}$ Only four companies/enterprises out of 79 in the city employed more than 100 personnel in 1895 (Polzin and Witt 1974, 59).
} 
granted until 1868, and freedom of trade was first declared in 1869 (Kuna and Deya 2007). The city held on to its pre-modern municipal laws until 1871, and these laws were not replaced until the first unified German civil law code went into effect in 1900. The dissolution of the guild system in Rostock did not start until 1871, and was a gradual and tough process that was finally completed in 1890 (Schröder 2003, 140) ${ }^{15}$. Rostock's commitment to grain export arose from the agricultural structures of the province's hinterland, which was dominated by manorial landowners who used their influence to delay the introduction of incentives for industrial production and export (Manke 2000). In contrast to cities like Hamburg, Bremen, and Stettin, which had developed modern harbors with excellent transport connections, Rostock's docks were becoming increasingly antiquated (Karge, Schmied and Münch 2004, 135). Despite its maritime past and the development of the shipbuilding industry, the city only partially shared the socioeconomic and demographic characteristics of other European (and German) port cities ${ }^{16}$.

\section{Table 1: somewhere here}

The occupational and social structure of the city did not change very much between the two censuses (see Table 1). A relative decline over this time period in the number of agricultural and service workers was accompanied by an increase in the number of whitecollar and unskilled workers (including factory workers), but the percent change was rather small. More than half of the adult male population was engaged in production and transport jobs, while the share of unspecified workers, who were mainly employed in industry and were born outside of the city, grew. Domestic service (including cooks) comprised more than half of the female workforce in 1867, and still made up almost 40 percent in 1900.

\section{Marriage, household formation, and celibacy}

The average age at first marriage was high, and remained quite stable in the city between 1819 and 1867. The Singulate Mean Age at Marriage (SMAM) yields very similar results for

\footnotetext{
15 There were still 60 different guilds in Rostock in the second half of the $19^{\text {th }}$ century (Archiv der Hansestadt Rostock (AHR): 1.1.3.20 / 192, List of Ämter, drawn up in 1883). The last one to vanish was the fishing guild (Fischamt), which existed until 1945 (AHR: 1.2.7, Findbuch).

${ }^{16}$ For the features that are attributed to port cities and are thought to account for their distinct demographic, economic and social characteristics, see: Lee 1998; Lee and Marschalck 2000, 374-375; also Sharlin 1978; Oris 2003.
} 
the first two censal years: age 30.4 for men and age 27.4 for women in 1819, and age 30.3 for men and age 28.2 for women in 1867 (Szołtysek et.al. 2009). The critical change took place between 1867 and 1900, when a significant decline in the age at marriage was seen for both sexes (to 27.4 for men and 25.1 for women). This change in the age at marriage is confirmed by an analysis of the ages at first marriage in the parish of St. Jakobi, the largest of the parishes in the city. The ages at marriage were highest around 1860, and decreased thereafter until 1900, when they were about four years lower (Kohagen 2010: 115). The major reasons for this development were the introduction of compulsory civil marriage in 1875 in Germany, which made access to marriage easier, and the removal of older restrictions on nuptiality ${ }^{17}$. In this year, a small marriage boom actually seems to have taken place in Rostock (Kohagen 2010: 78).

\section{Figures 2-3 somewhere here}

Figures 2 and 3 present the proportions of ever-married persons by single years, first separately for men and women, and then for the male population broken down by the occupational sector. In both cases, important differentials in nuptiliaty patterns are revealed. Around 79 percent of men and women were already married by age 30 in 1900, compared to 55 percent of men and 60 percent of women in the previous census. Particularly among males, a shift towards younger marriage had the effect of greatly increasing the number of evermarried individuals in age groups previously dominated almost entirely by celibates (only five percent males were married by age 25 in 1867, compared with 35.8 percent in the next census).

Figure 3 illustrates three different nuptiality regimes and the associated patterns of behavioral adaptation to the changing socioeconomic and institutional environments. Only minor changes were seen among professional, administrative, clerical, and sales workers ("others"). In both censuses, males from those groups were shown to be marrying the latest, a trend that can also be seen in the SMAM figures for this subpopulation (31.4 in 1867, and 30.2 in 1900). Members of these groups appear to have represented more "traditional" subsets of society who were potentially less affected in their nuptiality behavior by the processes of social change.

\footnotetext{
${ }^{17}$ According to Dietzsch $(1918,30)$, the law in the Grand Duchy of Mecklenburg-Schwerin required every man to have a domicile before getting married. Dispensation was possible for those who intended to emigrate.
} 
By contrast, a significant change in marital behavior could be observed among skilled workers. For this group, the value of SMAM dropped by almost five years during the intercensal period (from 31.5 to 26.7 years). Whereas only 32 percent of males in this occupational sector were married by the age of 28 in the 1867 census, 79 percent of male respondents in the same age and occupational categories were married some 30 years later. It seems plausible to link this apparent increase in marriage opportunities to the gradual liberation from the restrictions of the declining guild system taking place in the city throughout the 1870 s and 1880s (Lynch 1991, 80-82; also Lee 1999, 177; Lee 2000).

As early as in 1867, the mean age at marriage among unskilled workers was the same as the age among skilled workers in 1900 (26.8 years). It fell further in the inter-censal period, reaching 24.4 years in 1900. This pattern of change was almost exclusively achieved through an increased propensity to marry among younger males. Whereas in 1867 only 16 percent of males were married by the age of 25 , this figure had quadrupled in the next enumeration ${ }^{18}$.

Another dimension of nuptiality differentials around 1900 is related to the effect of migration. People born outside of Rostock married younger than the native-born population: the SMAM for native-born men in 1900 was 28.4 , compared to 27.1 for the immigrants, while the respective figures for women were 25.9 years and 24.8 years. The difference is rather small, but it actually masks huge occupational differentials. The difference is particularly revealing for unskilled workers. While the average person born in Rostock married for the first time at the age of 26.7, the average resident who came from outside the city married three years earlier. As a consequence, the marriage pattern for the latter category does not appear to be an "exaggerated" version of the European Marriage Pattern: not only did these males marry relatively early; but, after the age of 45 , the share of celibates in this group disappears almost entirely. Other occupational groups showed the same trend, but the magnitude was smaller (see Table 3; also Lynch 1991, 84-87) ${ }^{19}$.

\footnotetext{
${ }^{18}$ Our discussion of Figure 3 complies with the earlier observations of Ehmer, who, in contrasting Central Europe to England, associated the decline in age at marriage with later stages of industrialization (Ehmer 1991).

${ }^{19}$ The nuptiality pattern of migrants to Rostock stands in marked contrast to the patterns of other industrializing cities, where, according to a number of studies, migrants always married later than natives (e.g., Alter 1988; Brändström, Sundin \& Tedebrand, 2000; Oris, 2000; also Lynch 1991, 84-85; recently Moreels and Matthijs 2011). It also differed from the patterns found for Bremen, where family formation among immigrants was significantly delayed relative to the native-borns. Also, men and women in Bremen generally married earlier than in Rostock (native-born men married for the first time at an average age of 28.4, and women at an average age of 24.5 years; while the respective ages for immigrants were 29 and 26.6; see Lee and Marschalck 2002, 263-264). Constrained nuptiality due to skewed sex ratios and gender-specific migration streams and
} 
Within-city spatial differences in nuptiality call for a separate discussion. Whereas in the earlier census differences between the city districts in the proportions of the ever-married were by no means unequivocal, by the end of the century, a clear differentiation had emerged. Two newly developed suburbs (KTV and STV) were then occupying positions at the two extremes, with the former clearly displaying an earlier marriage pattern, and the latter the latest pattern of all the city districts. Whereas the average man living in KTV around the turn of the century married at age 26.3 , and the average woman at age 23.5 ; their counterparts in the southern suburb of STV did so three and almost six years later, respectively. These differences were concomitant with the socioeconomic profiles of the two neighborhoods, with the unskilled workers of KTV following the early marriage patterns generally typical of their own occupational group, and with white-collar people and tradesmen of STV marrying significantly later.

There are two other processes that should be studied in conjunction with nuptiality: leaving home and household formation. The problem of leaving home is very complex. Here we approach it in only a very cursory way, by focusing on the direction and the crude magnitude of change occurring between the censuses. To start with, we simply divided the Rostock population into those who were living with one or both of their parents, and those who were not. We focus on the first group, which we equate with those who had not yet left the parental home $\mathrm{e}^{20}$.

\section{Figure 4: somewhere here}

Figure 4 presents the age-specific proportions of parental co-residence broken down by sex and censal year. It shows that, on average, men left home significantly later in 1900 than in 1867. In the earlier census, 52.1 percent of males aged 15 were still living with their

employment structure was considered typical for many European port cities (see Lee 1998, 155-156; Lee 2000). For criticism of this view, see Lynch 1996, and Oris 2000.

${ }^{20}$ Cross-sectional census data are hardly the ideal source with which to study this process, as well as other forms of migratory movements. Several methods have been proposed to study how children disappear from the parental home in the current-status data. It has been suggested, for example, that the proportion of children residing with their parents between the ages of 15 and 19 be compared with the same proportion between the ages of 10 and 14 (e.g., Wall 1987). The method presented here is very reminiscent of one of the techniques used by Schürer in his analysis of the home-leaving process in England (Schürer 2003). This approach is far from perfect, since the distribution and intensity of adult mortality can influence the shape of the curve presented in Figure 4. 
parents, compared to 63.1 percent some 30 years later. The difference at age 24 is even more striking, as the percentage of men still living with at least one parent at that age in 1900 was twice as high as in the 1867 census. Only by the age of 25 do the curves charting the proportions of males living with their parents converge in the two censuses at levels of around 18 to 20 percent. Not only did men tend to leave the parental home later in 1900 than in 1867 ; they also spent a much shorter fraction of their life course living as non-kin residents of domestic groups (servants, apprentices, journeymen, or lodgers). For women, however, there was almost no change between the censuses. In 1867, males left the parental home earlier than females (there was a relative difference of around 10 percent). In 1900, there was almost perfect equality of the sexes in this regard.

Yet behind these general trends lies a wide diversity of experiences. Male patterns, in particular, might well be the composites of various distinct patterns that depend on the migratory history ${ }^{21}$ and the social and occupational characteristics of individuals, even though a general delay in leaving home was occurring across all occupational sectors of the society in 1900. For example, although men in handicraft left home later, thereby reducing their premarital exposure to living as a non-kin (apprentices, journeymen) in the households of others, a more extreme form of this pattern could be observed among unskilled workers (see Figure 5). The major change experienced by the latter group between the censuses was related to a dramatic reduction in the boarding phase when workers lived with non-kin between leaving home and starting a family. As a consequence, for many unskilled workers from around 1900, a decision to leave the parental home was directly followed by marriage. The above pattern could be seen in the distribution of population in the city. Delays in leaving home could be observed among the subpopulations of all of the city districts except the KTV area, where residents tended to leave the parental home more rapidly in 1900 than in 1867.

\section{Figure 5: somewhere here}

The parallel trends in 1900 of remaining in the parental home longer and of marrying at younger ages are very interesting, if only because these developments indicate the decreasing importance of a life stage which traditionally allowed individuals to accumulate resources that could be used subsequently in family formation (Hartmann 2004; de Moor and

\footnotetext{
${ }^{21}$ For example, using the "crossover-point" method described in Schürer (2003), we estimated that around 1,900 men born in Rostock left the parental home at the age of 25 . Those born outside the city did so at age 15 . See footnotes 10 and 20 with regards to caution needed in interpreting these figures.
} 
van Zanden 2010). Shortening this "acquisitory" phase in the life course might have led to an increase in the number of males on the marriage market who were less endowed with the skills, "positions," or earnings necessary to support a family, which may have endangered the balance between population and economic resources. This is why our next step is to investigate the relationship between marriage and household formation.

In both 1867 and 1900, the age-specific headship rates for men rose steadily up to ages 30-35, and reached a plateau thereafter. The only significant discrepancy between the censuses occurred among the elderly (65+), whose headship rates were five percent lower in 1900. What really matters in understanding the process of household formation is the actual relationship between marriage and entry into headship (Hajnal, 1982, 463 ff.). Data in both censuses that is of relevance to explaining this important link among males suggests that, on average, marriage was not occurring until after household formation. This trend becomes clear when we compare the difference between the age at marriage (SMAM) and the age at assuming headship (Singulate Age at Household Formation/SMAHF) (Table 2). Since this difference was generally small, we can assume that there was quite a strong association between family formation and becoming a household head in both 1867 and 1900. By the end of the century this association had become even stronger, as the absolute difference between the SMAM and the SMAHF had declined from around 11 months to five months. The phase of living as a solitary household head before marriage was shortened to a greater extent for those segments of urban society among whom this difference was larger in 1867. Interestingly, it was shorter for people born in Rostock than for the non-natives ${ }^{22}$.

\section{Table 2: somewhere here}

\footnotetext{
22 Theoretically, the heading of households by never-married adults could result from either intentional household formation by young adults, or the transmission of headship occurring in response to the abrupt death of the older family member who was previously in charge of the domestic unit. In our case, the overwhelming majority of those unmarried male household heads were in charge of solitary households (80 percent in the age group 20-29 years in 1900, and more than 90 percent in 1867). This is confirmed by an analysis of unmarried men of the same age group who lived with a mother, but no father (a constellation after the death of the father as the male household head): in 1900 only five percent of this group were registered as heading a household, while in 1867 the share was, at one percent, even lower at. Those unmarried men heading a household in Rostock were therefore clearly establishing a new household and not taking over an existing household after the death of the previous household head.
} 
All in all, the congruence of the declining age at marriage and the strong relationship between marriage and attaining headship suggest that opportunities for establishing domestic economies were increasing for young adults in the city, both single and married. This could only happen in an environment in which employment, income opportunities, and the availability of housing were increasing ${ }^{23}$. Both processes, as we have already indicated, were at work in Rostock during the inter-censal period. The fact that more than half of the youngest male household heads in 1900 (ages 20-24) were actually residing in the newly developing $K T V$ district also supports this argument.

Permanent celibacy is another aspect of nuptiality behavior which requires investigation. It is a common assumption in historical demography that the proportion of never-married people should be positively correlated to the age at marriage. Permanent celibacy, the argument goes, is merely a consequence of delayed marriage (Engelen and Kok 2003, 97). Data provided in Table 3 suggests this notion can be generally accepted for Rostock.

\section{Table 3: somewhere here}

At the aggregate level, the observed decline in the age at marriage between the censuses was accompanied by a decrease in the proportions of never-married males and females aged 4554. However, despite a significant lowering of the female age at marriage between 1867 and 1900 , relatively high rates of celibacy were still seen among women at the end of the period $(14.5 \text { percent })^{24}$. It is also clear that this general tendency did not apply to all social groups, as among skilled workers, earlier marriage was also accompanied by an increased proportion of celibates in 1900. Yet the most surprising pattern can be observed among the migrants, especially women. It might be expected that people who come from outside of the city would have fewer resources (and other constraints imposed on them as well, such as crafts guilds' restrictions on gaining citizenship), which would limit their access to marriage and lead to significant rates of permanent celibacy among them (Sharlin 1978). This was obviously not the case in Rostock. This is a complex problem (e.g., the time spent in the city before marriage, selection effect, differences in marital strategies between social groups, etc.; see

\footnotetext{
${ }^{23}$ Between 1850 and 1914 real wages increased more than twofold in Germany (König 2000, 124).

${ }^{24}$ Of the women in the province of Mecklenburg-Schwerin, 9.8 percent were celibate in $1885,9.3$ percent in 1890, and 9.3 percent in 1910 (Szołtysek et.al 2010).
} 
Lynch 1991; Oris 2003, 192; Moreels and Matthijs 2011) which we cannot deal with in this paper.

Spatial clustering within the city also resurfaced with regard to celibacy. This can be seen in the distinct behavioral patterns of two major suburbs. In both censuses, rates of celibacy were highest among the STV female population aged 45-54, and these rates increased over time (from 21 percent in 1867 to 27 percent in the second census). This trend was counterbalanced by the very low, and further decreasing, values of the variable in the KTV area (11.5 percent in 1867, and eight percent in 1900).

\section{Household structure and composition}

Changes and variations in the kin component of the co-resident domestic groups (that is, among persons who shared a clearly defined living space or dwelling), are often considered to be the most powerful indicators of change and diversity in family systems (Laslett 1972). In a given community, a change in the household structure may, all other things being equal, reflect an important shift in preferred or achievable residential patterns. It may also indicate a change in the way obligations toward kin from outside of the immediate family circle are structured (Das Gupta 1997). Households that differ in structure may perform their welfare functions on an altogether different basis (Cain 1991), and may cope with economic hardships in a different manner (Laslett 1988).

Nearly three-quarters of all households in 1867 in Rostock had a nuclear structure, and, apart from solitaries, the numbers of all other types of domestic groups were negligible (Table 4). The cumulative percentage of all complex households (extended and multiplefamily combined) only slightly exceeded eight percent. Out of nearly 7,000 households, only four displayed a multiple-family structure. This structural distribution of household types in Rostock underscores the prevalence of a strictly nuclear family system in the city, which was also characterized by a significant share of solitary households ${ }^{25}$.

\section{Table 4: somewhere here}

The comparison with 1900 reveals that only very minor shifts in the proportions of different household types occurred between the censues. There was a very slight increase in

\footnotetext{
${ }^{25}$ Following Laslett, by solitary households we mean here domestic groups headed by solitary persons, and not exclusively single-person households.
} 
the share of nuclear families, accompanied by a decrease in the proportion of solitary domestic groups. There was basically no change in the category of extended households, although some compositional shifts occurred within subclasses (the share of domestic units with co-resident parent increased by 1900). The number of multiple-family households also remained negligible in the second census. Generally speaking, both censuses found that only a very small percentage of households were extended. Indeed, the percentage was smaller than in pre-industrial and industrializing England (Laslett, Wachter \& Laslett 1978, 70-72) ${ }^{26}$. Rostock had significantly fewer complex households than mid-19th-century Preston, where 23 percent of all households included related persons other than members of the conjugal family (Anderson 1971, 44). The overall pattern that can be seen in Rostock does not resemble the patterns of either the industrializing city of Duisburg, or of less progressive Graz in Austria ${ }^{27}$. If we assume that the socioeconomic changes that were taking place in Rostock between 1867 and 1900 had an effect on prevailing household structures, we must conclude that both observed changes in the household pattern are rather trivial.

In both censuses, the incidence rates of complex households were equally low across all city districts and all occupational groups. The neighborhoods differed, however, with regards to proportions of simple and solitary households. The KTV area assumed a leading position in 1867 due to its very high proportion of nuclear families and very low proportion of solitary households ( 84 percent and seven percent, respectively). This was an effect of a new settlement process taking place against the background of expanding housing structures. By 1900, the area's peculiar position within the spatial patterns of household structure in the city largely disappeared due to an increase in the share of solitaries and a decrease in the share of simple family households. By contrast, domestic group structures remained quite stable in the inner city comprising the Old and New Towns, with the latter retaining the lowest proportions of conjugal family households (67 percent) and the highest share of single-headed households (21 percent).

\footnotetext{
${ }^{26}$ Laslett proposed the figure of 10.1 percent extended households for pre-industrial England. In the city of Rotterdam, extended families varied from 6 percent to 13 percent of the population between 1810 and 1880 (Janssens 1986, 29).

${ }^{27}$ In Duisburg there was a significant decrease in the proportion of households with extended relatives, from 13.8 percent in 1867 to 5.6 percent in 1890; see Jackson 1997, 55, 163). In Graz, however, a reversal of this pattern was seen. In this city, the share of extended family households rose from 11 to 21 percent in the second half of the $19^{\text {th }}$ century (Hubbard 1976, 290).
} 
Occupational differentials in household structure were largely consistent over time, as well. Compared to other occupational groups, unskilled workers continued to be more inclined to form conjugal domestic units, and were less likely to live alone ( 85 percent and seven percent of all households, respectively, in both censuses). Among skilled workers, more households were headed by singles, while fewer were nuclear families. The real departure from the above patterns could be seen among white-collar workers, who were far more likely than other groups to form solitary households (above 25 percent), and were less likely to form simple family households (60 percent or below).

\section{Table 5: somewhere here}

Table 5 presents another way of approaching the issue of household composition and changes in households over time. The general stability in patterns of kin cohabitation between the censuses is corroborated here, with only a very slight increase in the overall percentage of co-residing relatives in the population. As expected, most of the change was related to the rise in living with parents, but its relative magnitude was very small. Much more important was the substantial decrease in the share of secondary unrelated individuals (servants, lodgers, and other non-kin). The fact that this shift mainly occurred in the servant population demonstrates that the traditional pattern, in which servants or other employees, such as apprentices, lived with their employers, was fading by 1900 (see also Table 4). This was probably one of the reasons why the population of the city turned to live in smaller households during the intercensal period $^{28}$.

This decline in service occurred simultaneously among all major occupational groups (although with varying intensity), but not across all neighborhoods. Both in 1867 and 1900, servant co-residence was most frequent in the households of white-collar workers and tradesmen, followed by domestic groups of skilled workers. The households of unskilled workers seldom included servants. The sharpest decline in the frequency of living with servants (in that context: mainly apprentices and journeymen) occurred among the households of skilled workers, decreasing from 32 percent in 1867 to 12 percent in 1900. However, the change among white-collar workers and people in trade was also substantial (from 40 percent

\footnotetext{
${ }^{28}$ The share of the population living in households with no more than six persons increased between the censuses, from 65.3 percent to 80.5 percent. Compared to Rostock, the decrease in the proportion of households with living-in servants was very slight both in Duisburg between 1867 and 1890 (from 12.1 percent to 10.8 percent), as well as in Graz between 1857 and 1900 (from 33.7 percent to 29.4 percent); see Jackson 1997, 163; Hubbard 1976, 290.
} 
in the first census to 26 percent in the second one). Out of four major city districts, three recorded a 50 percent decline in the proportion of households with servants. The southern suburb of STV was the only area of the city where the proportion increased between 1867 and 1900.

The numerical importance of particular household types among the populations under study can be better understood if we infer the intersection between individual and household life patterns from the age structure by household membership. Figure 6 provides estimates of the proportion of the entire population found in various types of households separately for 1867 and 1900.

\section{Figure 6: somewhere here}

Both datasets show that the overwhelming majority of children below age 15 (more than 80 percent) spent their childhood and early teenage years in nuclear households. There was only a slight increase in the propensity to live in extended households in both census years, a tendency which was otherwise very stable across all age groups in both censuses. Thus, living with relatives cannot really be attributed to any specific age group of the city's population in either 1867 or 1900. By contrast, solitaries (and people living in domestic groups involving no conjugal units) had a more pronounced life-course pattern: in both censal years, the only subset of the population who seemed to be strongly affected by this life-course change were the aged. In both 1867 and 1900, the elderly were far more likely to live in a solitary or nuclear household than in any other form of living arrangement.

To get a better sense of other possible shifts in the domestic group structure, we looked at changes in household composition based on the age of the household head. We found that nuclear households predominated throughout most of the life course in both censuses, except among the youngest heads (over 70 percent of male heads aged 25 to 64 were heading nuclear family households in both enumerations; for the elderly heads, see further in the text). In 1867 the overwhelming majority of the youngest heads were not yet married and lived in domestic groups involving no conjugal family core (mostly single-person households). The socioeconomic circumstances and occupations of these men varied, with some, for example, being students, and others unskilled workers or traders. It is hard to say whether this specific arrangement, whereby very young unmarried men were eligible and capable of heading households, represented some sort of an early industrial pattern which 
diminished once modernization processes escalated ${ }^{29}$. Around 1900 early household formation seems to have been essentially linked with the formation of a family.

\section{Intergenerational bonds}

Using the "dyadic approach," we can go even further in investigating individual relationship patterns within households, and even examine the changes that occurred over the life courses of individuals. By looking at all individuals irrespective of whether they were independent householders, we can also move beyond the limitations of a strictly household-level analysis. Since the observed patterns of kin incorporation in the city involved predominantly lineal extension, we can limit our examination to life-course changes in the strength of intergenerational bonds in two census years; namely, co-residence with children (married and not).

\section{Figure 7: somewhere here}

Figure 7 presents the proportions of people who lived with at least one child in Rostock by age and census year. There was a decrease in the share of elderly men co-residing with a child in 1900, but generally no change for elderly females. Among both sexes, however, the ages at which individuals were sharing a residence with children were falling, which is in line with the observed decline in the age at marriage, and, presumably, the beginning of the childbearing career. There were also more people living with children at middle ages in 1900 than in 1867, which was perhaps an effect of declining infant and child mortality. The change in nuptiality explains most of the difference in the individual life courses of younger adults between the censuses, but not the differences in the rates of coresidence with children at older ages. All other things being equal, living with children was a less common living arrangement among males in 1900, but not necessarily among females.

\section{Figure 8: somewhere here}

We now move to an investigation of more important aspects of intergenerational coresidence in Figure 8, which charts the rates of living with married children over an average life course in both censuses. First, co-residence with a conjugal family unit disposed

\footnotetext{
${ }^{29}$ This pattern persists even if the subpopulation of students is excluded from the pool of household heads.
} 
downwards never affected more than one-fifth of the oldest group of the Rostock population. Second, this type of kin co-residence was highly skewed, as it occurred predominantly in the latest stages of a person's life. There was also a clear pattern of change between the censuses. Figures 7 and 8 together show that a decreasing propensity to live with children between 1867 and 1900 was accompanied by a somewhat greater likelihood of co-residing with at least one married child at older ages. However, the extent of the change was quite small on average. Adjusting the figure for the three-year decrease in the age at marriage reduces the difference, but the message remains the same: in relative terms, more people lived with married children in 1900 than in 1867.

A breakdown of the 1900 data by male and female migratory status shows that a lion's share of the observed increase in co-residence with married children at older ages was due to the specific residential behavior of immigrant families. Elderly people born outside the city tended to reside with their married children more often than the native-borns (13 percent versus four percent among males aged 75-79; 22 percent versus nine percent among females in the same age group $)^{30}$. Equally interesting is the differential behavior of the elderly in the KTV suburb. In this traditionally working-class district, a stronger inclination towards intergenerational co-residence at old age had developed by the end of the century. This peculiarity is partly explained by the higher proportions of widowed people among the aged in the KTV, as the elderly co-residence rates with married children were highest for widowed people.

So far we have focused on cases of co-residence with close relatives, and used changes in their respective proportions over time to extrapolate possible changes in the strength of intergenerational bonds. However, it is equally interesting to look at the patterns of "unrelatedness," and how they evolve over time. Family historians and historical demographers have devoted considerable attention to the study of people who were residing without family, whether as household heads, or as inmates, lodgers, or boarders attached to households of non-kin. The increasing share of primary and secondary unrelated individuals has been rightly identified as one of the most profound by-products of the modernization and industrialization processes occurring in the urban environment (Modell and Hareven 1977; recently Ruggles 1988; Baskerville 2001). Figure 9 seeks to capture this phenomenon in Rostock.

\footnotetext{
${ }^{30}$ The traditionally held distinction between migrants and non-migrants in terms of their comparative likelihood to form extended family arrangements was challenged by Janssens (1993, 189-192).
} 


\section{Figure 9: somewhere here}

There were two stages of life during which living as an unrelated individual (either alone or with non-kin only) was particularly common. The first was around the age of 20, as people were leaving home while the second was during old age. The first phase was very pronounced, with 70 percent of men in the age group 20-24 living without any kin in 1867, though this percentage fell to below 60 percent in 1900. The corresponding change for women in this age group was from 50 percent in 1867 to 40 percent in 1900. Thus, at least half of the women and three-quarters of the men were affected by this living arrangement in 1867, though these shares had declined by $1900^{31}$. In sum, we found that high proportions of young adults were living outside the parental household and not yet in a household of their own, but that this trend was clearly declining over time. These findings confirm the earlier results indicating that young adults were leaving home earlier and marrying at younger ages in 1900 . In both censuses, the proportions of unrelated individuals among elderly males were lower than among young adults of the same sex, but female populations behaved differently. More women than men became widowed, and, consequently, more women lived either alone or with children. However, we still see a similar decline in the proportions of elderly people living in such arrangements between the two censuses.

The lower aggregate rates of "unrelatedness" among late adolescents and young adults in 1900 actually mask the divergent behavior patterns of migrants and native-borns in the second census. The young men and women who lived as unrelated individuals were predominantly immigrants. The proportion of persons aged 20-24 in such residential circumstances was 75 percent smaller among native-born men than among immigrants. It was also 66 percent smaller among resident females aged 15 to 19 than among their in-migrant counterparts. In the later stages of life, however, the differences between the two subsets of the population were almost indistinguishable. Additionally, the major change among different occupational sectors involved a significant decrease in the share of unrelated individuals among young, unskilled workers (from 70 percent in the age group 20-24 in 1867, to less than 30 percent in 1900), which confirms our previous findings.

\footnotetext{
${ }^{31}$ This calculation was also redone with the category of students excluded from the pool of young men in the city. The proportions then decreased to 65 percent in 1867 and less than 60 percent in 1900.
} 
Another good indicator of the intergenerational co-residence patterns are the living arrangements of the aged (Ruggles 2009). Family systems may differ substantially in how they perform their welfare functions for the most vulnerable members of the population (Laslett 1988; Cain 1991; also Oris \& Ochiai 2002). This is particularly apparent in the residential patterns of elderly people (Kertzer \& Laslett 1995). What position do the elderly find themselves in, and how does this position change with urbanization in our case?

\section{Figure 10: somewhere here}

Representing about five percent of the city's population, the elderly (aged 65+) were a minority in Rostock. The majority of them were women, mostly widowed, while more than half of the elderly men were still married at that age. The living arrangements of the elderly hardly changed between the censuses (Figure 10). Two-thirds of men lived in simple family households, compared with less than half of the women did so. Instead, almost half of the women lived in households without a single conjugal family unit. On the other hand, about one-quarter of women lived in extended family households, while the respective proportion among men was lower. All of these patterns seemed to have been stable over time, and did not change between the censuses. The share of the elderly who lived in complex households increased between 1867 and 1900, but only very slightly. If the prevailing family system in Rostock, which was based on late marriage and nuclear household residence, caused hardships for the elderly (Alter 1996), this problem must had predated the developments of urban/industrial life in the city.

\section{Table 6: somewhere here}

The continuity of living arrangements among the elderly can be further understood by examining a change in the three broad types of their residential positioning in Rostock (Table 6). In both censuses, the majority of elderly men and women still co-resided with at least one member of their immediate conjugal family (three quarters of males and half of elderly females). The relative change over time was almost negligible in this regard, and can by no means be taken as an indication that a progressive residential isolation of the aged was occurring. This observation is generally supported by an examination of patterns among the potentially most vulnerable individuals in this age group: that is, those living alone or with non-relatives only. Here again we observe a downward trend among both sexes over time 
(from 21.9 to 19.6 percent for men, and from 38.4 to 34.7 for women). This observation runs contrary to the usual structural-functionalist assumptions regarding the effect of urban life on family, even though females remained more exposed to "nuclear hardships" than men in 1900. Finally, there is the issue of the empty nest stage of the family life cycle, during which the parents (or parent) are the only people left in the household after the departure of their children from the parental home. More men had experienced that stage of family life in 1900 than in 1867 , but the pattern was stable for women.

Apart from this overall picture, there were, however, major differences within the elderly population according to their marital status. Those living without any co-resident relatives of any kind were a majority among the unmarried elderly, and made up almost half of the widowed elderly. In contrast, an empty nest stage was experienced by about 60 percent of married elderly women, and about half of married elderly men (with an increase over time for men only).

\section{Conclusions}

During the $19^{\text {th }}$ century, the city of Rostock underwent significant changes: the population increased substantially, population density rose, and the urban space expanded beyond the city walls. Towards the end of the century, industrialization gained momentum and provided an increasing number of jobs outside the traditional sectors of handicraft, trade, and transport. Nevertheless, the question regarding nature of the connection between those changes and the shifts among the components of the family system is not unlike the well-known dilemma of whether a glass is half empty or half full.

We undoubtedly observe a direct congruence between socio-structural and nuptiality changes in the population under study, although the changing institutional context was also involved in bringing this change about. During the time period between the censuses of 1819 and 1867, almost no familial change occurred (Szołtysek et al. 2009). However, between 1860s and 1900, the average age at marriage decreased by three years for both sexes. This was a substantial and quite a rapid transition, which was accompanied by a slow decrease in the originally very high proportion of never-married people.

The nuptiality change seems to have been the impetus behind most of the other familial modifications observed. First and foremost, it triggered changes in the life-course transitions of individuals, such as the ages at leaving home and household formation. The age at leaving home increased for young men, but not for women. Developments in nuptiality 
were accompanied an increased pace of domestic unit formation, which served to strengthen the connection between marriage and new household formation in 1900. Developing housing structures within the newly expanded city boundaries provided for this apparent association between marriage and neo-local residence. The concurrence of a delayed process of leaving home, earlier entry into marriage, as well as decreasing age at becoming a household head, resulted in the substantial reduction in the premarital trend among young adults of living as non-kin in household of others. In particular, the traditional patterns of servants or other employees living with their employers had diminished substantially by 1900 .

By contrast, the effects of economic and societal changes on the composition of households were negligible. Co-residence in simple family households remained the dominant pattern. The overwhelming majority of co-resident domestic groups in Rostock were nuclear before, during, and after industrialization. The extension of nuclear family households was a minor phenomenon, and remained constant over time. There was a slight decrease in the percentage of solitary households, but a sharp drop-off in co-residence as unrelated individuals, including as servants, apprentices, or journeymen. This development continued well into the $20^{\text {th }}$ century and resulted in the eventual disappearance of this kind of living arrangement.

Household types among the elderly did not seem to change in the period under investigation. Changes in co-residence rates with children reflected the younger age at marriage; apart from this shift, a slight increase in co-residence with married offspring among the oldest residents was the only other change that occurred. A dyadic approach generally corroborates the general trend posited using more traditional measures: the likelihood of the elderly co-residing with married children increased only very slightly between the censuses. A progressive residential isolation of the aged can hardly be proved for Rostock.

The persistence of household structures in Rostock might be surprising, as is the fact that the continuity of the family pattern in the city rested primarily on the tenacity of nuclear family-centered patterns of co-residence. If, therefore, continuity is revealed to be among the prevailing themes of our study of historical residence patterns, what was its source?

The role of the guild system must first be mentioned, as its dissolution in Rostock was a slow and tough process that was not fully completed until around 1890 (Schröder 2003, 140). It is a well-known fact that crafts guilds were usually able to influence individual behavior by restricting access to marriage. By perpetuating values stressing the association between marriage, independent economic position, and neo-local residence, they might have also helped in sustaining the prevalence of the simple family model over the long run among 
the city dwellers (Lynch 1991, 80-81, 92-93). Also relevant is the observation that the general pattern of household composition in late-19th-century Germany leaned strongly towards simple domestic group structures (Szołtysek et. al. 2010). We can also tentatively assume that simple domestic structures dominated among the rural population of the Mecklenburg hinterland of that time ${ }^{32}$, making it unlikely that rural migrants would have brought to their urban destinations patterns of family life other than those resembling the conjugal households typical of their areas of origin. Finally, it has been argued that urban family structures generally tended to be predominantly nuclear, irrespective of time and space, although the specific patterns that prevailed in the countryside might have had an additional effect on who lived with whom in the city (Solli 2010; Gruber 2008; Kaiser 1992).

It could be argued that, because Rostock was less affected than other areas by the changes resulting from large-scale industrialization, proletarianization, and "paroxystic" (Bourdelais 2000, 364) population growth, our setting is not suitable for examining the Parsonian perspective on the relationship between industrialization and the family ${ }^{33}$. Seen through these lenses, the marked durability of household structures between 1867 and 1900 in the city could be taken as a manifestation of inertia resulting from the partial and incomplete character of the structural changes of the local economy. This argument can, however, be refuted on the basis of our knowledge of cases from 19th-century Europe in which significant changes took place in a city's household structure without any major socioeconomic processes being involved, apart from growth in the population growth (Zyblikiewicz 2010).

While we were initially led by structuralist family theories in our analysis of the impact of socioeconomic changes on the prevailing family system in Rostock, it is obvious that the pattern and direction of family change may not be as straightforward and direct as these theories postulated. The general theory of family nuclearization is, indeed, too general, simplistic, and mechanistic (e.g., Litwak 1960; also King and Timmins 2001, 263-271). The term "industrialization" may mask a variety of macro-level forces, and the impact of industrialization on co-residential processes is determined by the type of industrialization that

\footnotetext{
${ }^{32}$ The agrarian landscape of East Elbian Germany (and Mecklenburg in particular) was dominated by large manorial farms and by the rural strata, consisting primarily of rural laborers with little or no land of their own and cottagers, but only a small number of independent middle-strata peasant farmers (Constantine 2007, 1, 6, 24).

${ }^{33}$ It was designed to deal with "ideal types" of 19th-century industrial cities characterized by dramatic and allpervading change resulting from large-scale industrialization, proletarianization, and high rates of population turnover, which was too often the exception in historical reality (Janssens 1993, 244).
} 
is occurring in a given setting. It has therefore been argued that "industrialization" is likely to have different effects on co-residence patterns and processes at different times and in different places (Kertzer and Schaffino 1983; Arcury 1990; recently King and Timmins 2001, 276278). Recently, urban and labor historians have proposed several generalized frameworks designed to better conceptualize these diverging socioeconomic influences on the demographic conduit of populations and communities that differ in their profiles and characteristics (Haines 1979 for mining communities; Bourdelais 2000 for metallurgic centers; Lawton and Lee 1989, and Lee 1999 for port cities) ${ }^{34}$. The problem from the point of view of this study is that Rostock does not seem to fit well into any of these frameworks. Although population growth in Rostock was quite substantial over the period under investigation, it lagged far behind the "paroxystic" levels of industrializing metallurgic centers. Despite the continuous flow of immigration to the city, no traces of a large imbalance between the sexes can be found in our location. At the same time, the demographic behavior of the immigrants in Rostock displayed several peculiarities, especially regarding nuptiality. Finally, a general lack of constraints on residential development provided for many specific features of the familial system in the city between 1867 and 1900.

Generalizations are always risky, as trends differ between countries and across periods, and exceptional cases can always be found. Nevertheless, it seems that comparative research on places with different demographic and socioeconomic characteristics must be conducted before a more thoughtful model of the relationship between "industrialization(s)" and demographic behavior can be developed-particularly a model that pays sufficient attention to changes in various components of the family system. Some attempts to realize this goal are already underway ${ }^{35}$.

\section{ACKNOWLEDMENTS}

This article is a revised and expanded version of the paper presented at 35th Annual SSHA Meeting, session Social change and family change I: The impact of urbanization and industrialization on family systems, Chicago, 18-21 November 2010. We wish to

\footnotetext{
${ }^{34}$ The problem of household formation and residence patterns is, however, generally neglected in these studies.

${ }^{35}$ The research network coordinated by the Laboratory of Historical Demography at Max Planck Institute for Demographic Research aims at stimulating further empirical research and theoretical reflection about the effects of urban change on household formation and residence patterns in different industrial settings of Europe. The network links researchers working on urban sites of Rostock, Bergen (Norway), Krakow (Poland), Ostrava (Czech Republic), Antwerp, and Stockholm.
} 
acknowledge the continuous support for the realization of this project we have received from the director of Max Planck Institute for Demographic Research, Joshua R. Goldstein. We also wish to thank Martin Dinter (MPIDR) for providing data management and research assistance. Finally, we want to thank Katherine Lynch and George Alter for their comments on an earlier version of this paper.

\section{REFERENCES:}

ALTER, G. (1996). The European Marriage Pattern as solution and problem: Households of the elderly in Verviers, Belgium, 1831. The History of the Family 1-2:123-138.

ANDERSON, M. (1971). Family Structure in Nineteenth-Century Lancashire (Cambridge).

ARCURY, T. (1990). "Industrialization and Household Family Life Characteristics: Appalachian Kentucky Young Adults in 1880 and 1910," Journal of Family History 15; 285-312.

BASKERVILLE, P. (2001). Familiar Strangers: Urban Families with Boarders, Canada, 1901. Social Science History 25(3): 321-346.

BERQUO, E. and P. XENOS, (Eds.), 1992. Peter Family Systems and Cultural Change (Oxford: Clarendon Press).

BOURDELAIS, P. (2000). Demographic Changes in European Industrializing Towns. Examples and Elements for Comparison. The History of the Family 5(4), 363-372

BOURDIEU, J., KESZTENBAUM, L. and G. POSTEL-VINAY (2010). Living Together, Growing Old Together. Fragments for a history of coresidence in France during the Industrial Revolution. Paper presented at 35th Annual SSHA Meeting, Chicago, 18-21 November 2010.

BRÄNDSTRÖM, A., SUNDIN, J., \& TEDEBRAND, L-G. (2000). Two cities. Urban migration and settlement in nineteenth-century Sweden. The History of the Family 5(4), 415-429.

CAIN, M. (1991). 'Welfare Institutions in Comparative Perspective: The Fate of the Elderly in Contemporary South Asia and Pre-Industrial Western Europe', pp. 222- 243 in Life, death, and the elderly: historical perspectives, eds. Margaret Pelling \& Richard Michael Smith. London: Routledge.

CONSTANTINE, S. (2007). Social Relations in the Estate Villages of Mecklenburg c.1880-1924. Aldershot: Ashgate.

DAS GUPTA, M. (1997). Kinship systems and demographic regimes. In: Anthropological demography: toward a new synthesis, edited by David I. Kertzer and Tom Fricke. Chicago, Illinois, University of Chicago Press, 36-52.

DE MOOR, T. and J. L. VAN ZANDEN (2010). "Girl power: the European marriage pattern and labour markets in the North Sea region in the late medieval and early modern period". Economic History Review 63, 1-33.

DIETZSCH, E. H. (1918). Die Bewegung der mecklenburgischen Bevölkerung von 1850 bis 1910. Ein Beitrag zur politischen und volkswirtschaftlichen Geschichte des Großherzogtums Mecklenburg-Schwerin. Schwerin: Herberger.

EHMER, J. (1991). "Heiratsverhalten, Sozialstruktur, ökonomischer Wandel. England und Mitteleuropa in der Formationsperiode des Kapitalismus", Göttingen: Vandenhoeck \& Ruprecht, p. 324.

ENGELEN T., KOK J., (2003). Permanent Celibacy and Late Marriage in the Netherlands, 18901960. Population 58(1): 67-95.

GOODE, W.J. (1963). World revolution and family patterns. Glencoe, IL: Free Press.

GOODE, W. J. (1966). "Industrialization and Family Change." In Industrialization and Society, edited by Bert F. Hoselitz and Wilbert E. Moore, New York: UNESCO, 237-55.

GROENKE, E. (1982), Industrielle Entwicklung Rostocks in der zweiten Hälfte des 19. Jahrhunderts. In Stadtarchiv Rostock et.al. (ed.), Beiträge zur Geschichte der Stadt Rostock, Neue Folge, Heft 2, pp. 3-22, Rostock: Ostsee-Druck.

GRUBER, S. (2008). Household structures in urban Albania in 1918. The History of the Family Volume 13(2), pp. 138-151.

GRUBER, S.; SCHOLZ, R. D.; SZOŁTYSEK, M. (2010). Real and synthetic household populations 
and their analysis: an example of early historical micro-census data (Rostock, 1819). WP2010-017, MPIDR Working Papers.

HAAK, H. (1977). Bevölkerungswachstum in Mecklenburg-Schwerin 1819 bis 1905, In:

Wissenschaftliche Zeitschrift der Wilhelm-Pieck-Universität Rostock, Gesellschafts- und Sprachwissenschaftliche Reihe, Vol. 26, 1977, Issue 10, pp. 931-936.

HAJNAL J. (1965), "European marriage patterns in perspective" in GLASS David V. and EVERSLEY David E. C. (eds.), Population in History. Essays in historical demography, London: Edward Arnold, pp. 101-143.

HAJNAL J. (1982), "Two kinds of preindustrial household formation system", Population and Development Review, 8 (3), pp. 449-494.

HAREVEN T.K. (1978), "The Dynamics of Kin," in Turning Points, ed. John Demos and Sarane Boocock (Chicago), 151-181.

HAREVEN T.K. (1982). Family Time and Industrial Time (New York: Cambridge University Press).

HAREVEN T.K. (2000). Families, History and Social Change. Life Course and Cross-cultural Perspectives. Boulder: Westview Press.

HARTMAN, M. S. (2004). The household and the making of history. A subversive view of the western past. Cambridge: Cambridge University Press.

HUBBARD, W. (1976). Forschungen zur städtischen Haushaltsstruktur am Ende des 19. Jahrhunderts: Das Grazhaus-Projekt. In W. Conze, ed., Sozialgeschichte der Familie in der Neuzeit Europas. Stuttgart: Klett, pp. 283-291.

JACKSON, J. H. Jr. (1997). Migration and Urbanization in the Ruhr Valley 1821-1914. (Studies in Central European Histories.) Atlantic Highlands, N.J.: Humanities Press.

JANSSENS, A. (1986). Industrialization without Family Change? The Extended Family and the Life Cycle in a Dutch Industrial Town, 1880-1920. Journal of Family History, Vol. 11, No. 1, 2542.

JANSSENS, A. (1993). Family and Social Change. The Household as a Process in an Industrializing Community. Cambridge: Cambridge University Press.

KAISER, Daniel H. (1992). Urban Household Composition in Early Modern Russia. Journal of Interdisciplinary History, Vol. 23, No. 1, pp. 39-71.

KARGE, W., SCHMIED, H. \& MÜNCH, E. (2004). Die Geschichte Mecklenburgs. Rostock: Hirnstorff.

KERTZER, D. I. (1984). Family life in central Italy, 1880-1910 : sharecropping, wage labor, and coresidence. Rutgers University Press.

KERTZER, D. I. and SCHIAFFINO, A. (1983). "Industrialization and Coresidence: A Life Course Approach." In Paul B. Baltes and Orville G. Brim, Jr., eds., Life-Span Development and Human Behavior, vol. 5, 360-391. New York: Academic Press.

KERTZER, D. I. and LASLETT, P. (Eds.) (1995). Aging in the Past: Demography, Society, and Old Age, Berkeley and Los Angeles: University of California Press.

KING, M. (1990). "All in the Family? The Incompatibility and Reconciliation of Family Demography and Family History," Historical Methods, 23, pp. 32-40.

KING, M. and PRESTON S. H., 1990, "Who Lives with Whom? Individual versus Household Measures". In: Journal of Family History 15, 2, pp. 117-132.

KING, S. and TIMMINS, G. (2001). Making Sense of the Industrial Revolution. English Economy and Society, 1700-1850. Manchester: Manchester University Press.

KOHAGEN, C. (2010). Familiengründung ohne Trauschein - eine Analyse unehelicher Geburten im Rostock des 19. Jahrhunderts. Unpublished Master Thesis, Universität Rostock.

KÖLLMANN, W. (1959). Industrialisierung, Binnenwanderung und "Soziale Frage" (Zur Entstehungsgeschichte der deutschen Industriegroßstadt im 19. Jahrhundert). In: Vierteljahresschrift für Sozial- und Wirtschaftsgeschichte 46, pp. 45-70.

KÖNIG, W. (2000). Geschichte der Konsumgesellschaft (Vierteljahrschrift für Sozial- und Wirtschaftsgeschichte: Beihefte Nr. 154). Stuttgart: Steiner.

KUNA, E. and DEYA, H. (2007), Neues historisches Lexikon. E-Book. Haff Verlag.

LASLETT, P. (1972). Introduction. In P. Laslett \& R. Wall (Eds.), Household and family in past time (pp. 1-89). Cambridge: Cambridge University Press. 
LASLETT, P. (1983). Family and household as work group and kin group: areas of traditional Europe compared. In R. Wall \& J. Robin (Eds.), Family forms in historic Europe (pp. 513-563). Cambridge: Cambridge University Press).

LASLETT, P. (1988). Family, kinship and collectivity as systems of support in preindustrial Europe: a consideration of the »nuclear-hardship « hypothesis. Continuity and Change, 3(2), 152-175.

LASLETT, P., WACHTER, K.W., \& LASLETT, R. (1978). The English evidence on household structure compared with the outcomes of microsimulation. In K. W. Wachter, E. A. Hammel \& P. Laslett, Statistical studies of historical social structure (pp. 65-87). New York: Academic Press.

LAWTON, R. and LEE, R. (1989). Introduction: the framework of comparative urban population studies in Western Europe, ca. 1750-1850. In Richard Lawton and Lee, Robert Eds.), Urban population development in Western Europe: from the late-eighteenth to the early-twentieth century. Liverpool: Liverpool University Press, pp. 1-26.

LYNCH, K. L. (1991). The European Marriage Pattern in the Cities: Variations on a Theme by Hajnal," Journal of Family History 16(1): 79-96

LYNCH, K. L. (1996) "Geographic Mobility and Urban Life: Comparative Perspectives on American and European Demographic Trends in the Past," A lain Bideau et al. (eds) Les Systemes Demographiques du Passe, (Lyon) Programme Thone -Alpes de Recherches en Sciences Humaines, pp. 203-223.

LEE, W. R. (1981). The German Family: A Critical Survey of the Current State of Historical Research. In EVANS Richard J. and LEE William R. (eds.), The German Family: essays on the social history of the family in nineteenth- and twentieth-century, London [et. al.], Croom Helm [et. al.], pp. 19-50.

LEE, W. R. (1998), The socio-economic and demographic characteristics of port cities: a typology for comparative analysis? Urban History, 25: 147-172

LEE, W. R. (1999). Urban Labor Markets, In-Migration, and Demographic Growth: Bremen, 18151914. Journal of Interdisciplinary History - Volume 30, Number 3, Winter 1999, pp. 437-473.

LEE, W. R. (2000). Labour market constraints and the integration of urban in-migrants in nineteenthcentury Bremen. In: Leboutte, R. (Ed.). Migrations and Migrants in Historical Perspective. Permancies and Innovations. Peter Lang: Brussels, Bern, Berlin, Oxford, New York and Vienna, pp. 165-205.

LEE, W. R. and MARSCHALCK, P. (2000). Demographic change and industrialization in Germany, 1815-1914. Bremen in comparative perspective. The History of the Family 5(4), 373-390.

LEE, W. R. and MARSCHALCK, P. (2002). The porto-city legacy: urban demographic change in the Hansestadt Bremen, 1815-1910. In Robert Lawton and Robert Lee, eds., Population and society in Western European port-cities, c. 1650-1939 (Liverpool: Liverpool University Press), pp. 252-269.

LITWAK, E. (1960). Geographic Mobility and Extended Family Cohesion." American Sociological Review 25: 385-394.

MACFARLANE, A. 1987. Marriage and Love in England: Modes of Reproduction 1300-1840. Blackwell.

MANKE, M. (2000). Rostock zwischen Revolution und Biedermeier. Alltag und Sozialstruktur. Rostock: Neuer Hochschulschriftenverlag.

MEDICK, H. (1981) The protoindustrial family economy," pp. 38-73 in Industrialization Before Industrialization, ed. P Kriedte, H Medick, J Schlumbohm.

MODELL, J., and HAREVEN, T.K. (1977) "Urbanization and the malleable household: An examination of boarding and lodging in American families," in Tamara Hareven, ed., Family and Kin in Urban Communities, 1700-1930. NewYork: New Viewpoints: 164-86.

MOREELS, S. and MATTHIJS, K. (2011). Marrying in the City in Times of Rapid Urbanization. Journal of Family History 36(1) 72-92.

OEPPEN, J. and TOCH, M. (2010). Estimating the urban mortality penalty: Rostock and its hinterland 1786-1875. Paper presented at 35th Annual SSHA Meeting, Chicago, 18-21 November 2010.

ORIS, M. (2000). The age at marriage of migrants during the industrial revolution in the region of Liège. History of the Family 5(4): 391-413.

ORIS, M. (2003). The history of migration as a chapter in the history of the European family: An 
overview. The History of the Family, Volume 8, Issue 2, pp. 187-215.

ORIS, M., and E. OCHIAI (2002). "Family Crisis in the Context of Different Family Systems." In When Dad Died: Individuals and Families Coping with Distress in Past Societies, ed. Renzo Derosas and Michel Oris. New York: Peter Lang, 17-79.

ORIS, M. and ALTER, G.C. (2001). "Paths to the city and roads to death. Mortality and migration in East Belgium during the industrial revolution." In Recent Work in Belgian Historical Demography, Belgisch tijdschrift voor nieuwste geschiedenis - Revue belge d'histoire contemporaire, XXXI edited by I. Devos and M. Neven. 3/4: 453-495.

PARSONS, T., and BALES, R.F. (1955). The Family: socialization and interaction process. Free Press (Glencoe, Ill).

POLLA, M. (2006). Family systems in central Russia in the 1830s and 1890s. History of the Family, $11,27-44$.

POLZIN, M. and WITT, H. (1975). Rostock: von der bürgerlich-demokratischen Revolution 1848/49 bis 1945. Rostock: Hinstorff.

PRILL, S. (2010). Haushalts- und Erwerbsstruktur der Seestadt Rostock 1900. Unpublished Bachelor Thesis, Universität Rostock.

ROSENBAUM, H. (1996). Formen der Familie. Untersuchungen zum Zusammenhang von Familienverhältnissen, Sozialstruktur und sozialem Wandel in der deutschen Gesellschaft des 19. Jahrhunderts", Frankfurt am Main, Suhrkamp-Taschenbuch Wissenschaft 374: 7. Auflage, p. 633

ROTHENBACHER, T.F. (2002). "The societies of Europe. The European population 1850-1945", Houndmills [et al.], Palgrave Macmillan.

RUGGLES S. (2009). "Reconsidering the Northwest European Family System." Population and Development Review 35: 249-273.

RUGGLES S. (1990)., "Family Demography and Family History: Problems and Prospects." Historical Methods 23, pp. 22-30

RUGGLES S. (1988). The Demography of the Unrelated Individual: 1900-1950. Demography, Vol. 25, No. 4, pp. 521-536.

RUGGLES S. (1987). Prolonged Connections: The Rise of the Extended Family in NineteenthCentury England and America. Madison: University of Wisconsin Press.

SHARLIN, A. (1978). Natural decrease in early modern cities: a reconsideration, Past \& Present, no. 79, pp. 126-38.

SCOTT J. AND TILLY, L.A. (1975) "Women's Work and the Family in Nineteenth Century Europe," Comparative Studies in Society and History, 17, 36-64.

SCHRÖDER, K. (2003). „In deinen Mauern herrsche Eintracht und allgemeines Wohlergehen. Eine Geschichte der Stadt Rostock von ihren Ursprüngen bis zum Jahre 1990. Rostock: Ingo Koch Verlag.

SCHÜRER, K. (2003). Leaving home in England and Wales 1850-1920', in F. Van Poppel, M. Oris and J. Lee (eds.) The road to independence. Leaving home in Eastern and Western societies, 16th-20th centuries, Bern-Bruxelles: Peter Lang Publishing, pp.33-84.

SCHULTZ, H. (1975), Zur Herausbildung der Arbeiterklasse am Beispiel der mittleren ostelbischen Stadt Rostock (1769 bis 1870), IN: Jahrbuch für Geschichte, Band 13, pp. 153-201, Berlin: Akademischer Verlag.

SOLLI, A. (2010). Was there an urban household system in pre-industrial Europe? Paper presented at 35th Annual SSHA Meeting, Chicago, 18-21 November 2010.

SONNINO, E. (Ed.) (2004). Living in the city: 14th-20th centuries. Rome: Casa Editrice Universita la Sapienza.

SPOORENBERG, T. (2007). Quality of age reporting: Extension and application of the modified Whipple's index. Population-E 62 (4): 729-742.

SZOŁTYSEK, M.; GRUBER, S.; SCHOLZ, R. D.; ZUBER GOLDSTEIN, B. (2009). Social change and family change in a Central European urban context: Rostock 1819-1867. MPIDR Working Paper WP-2009-039 (2009).

SZOŁTYSEK, M.; GRUBER, S.; KLÜSENER, S.; GOLDSTEIN, J. R. (2010). Spatial variation in household structure in 19th-century Germany. MPIDR Working Paper WP-2010-030 (2010).

TODD, E. (1985), Explanation of Ideology: Family Structures and Social Systems (Family, sexuality, 
and social relations in past times). Blackwell.

TSCHARNKE, J. (1943). Anlässe und Gebiete der Volkszählungen in beiden Mecklenburg. Jur. Diss. Rostock.

VAN LEEUWEN, M. H. D., MAAS, I. and MILES, A. (2002). HISCO: Historical international standard classification of occupations. Leuven, Belgium: Leuven University Press.

WALL, R. (1987). Leaving home and the process of household formation in pre-industrial England', Continuity and Change 2: 77-101.

WALL, R. (1991). European family and household systems. In Historiens et populations. Liber Amicorum Etienne Helin (pp. 617-636). Louvain-la-Neuve: Academia.

WEBER-KELLERMANN, I. (1982). Die deutsche Familie. Versuch einer Sozialgeschichte", Frankfurt am Main, Suhrkamp, p. 268.

WRIGLEY E. A. (1977). Reflections on the History of the Family, Daedalus, Vol. 106, No. 2 , (Spring, 1977), pp. 71-85.

ZYBLIKIEWICZ, L. (2010). Society or societies? A comparative study of the two nineteenthcentury censuses in Cracov, Poland. Paper presented at 35th Annual SSHA Meeting, Chicago, 18-21 November 2010. 
Tables and figures

Figure 1: Age-sex distribution of Rostock population by census year

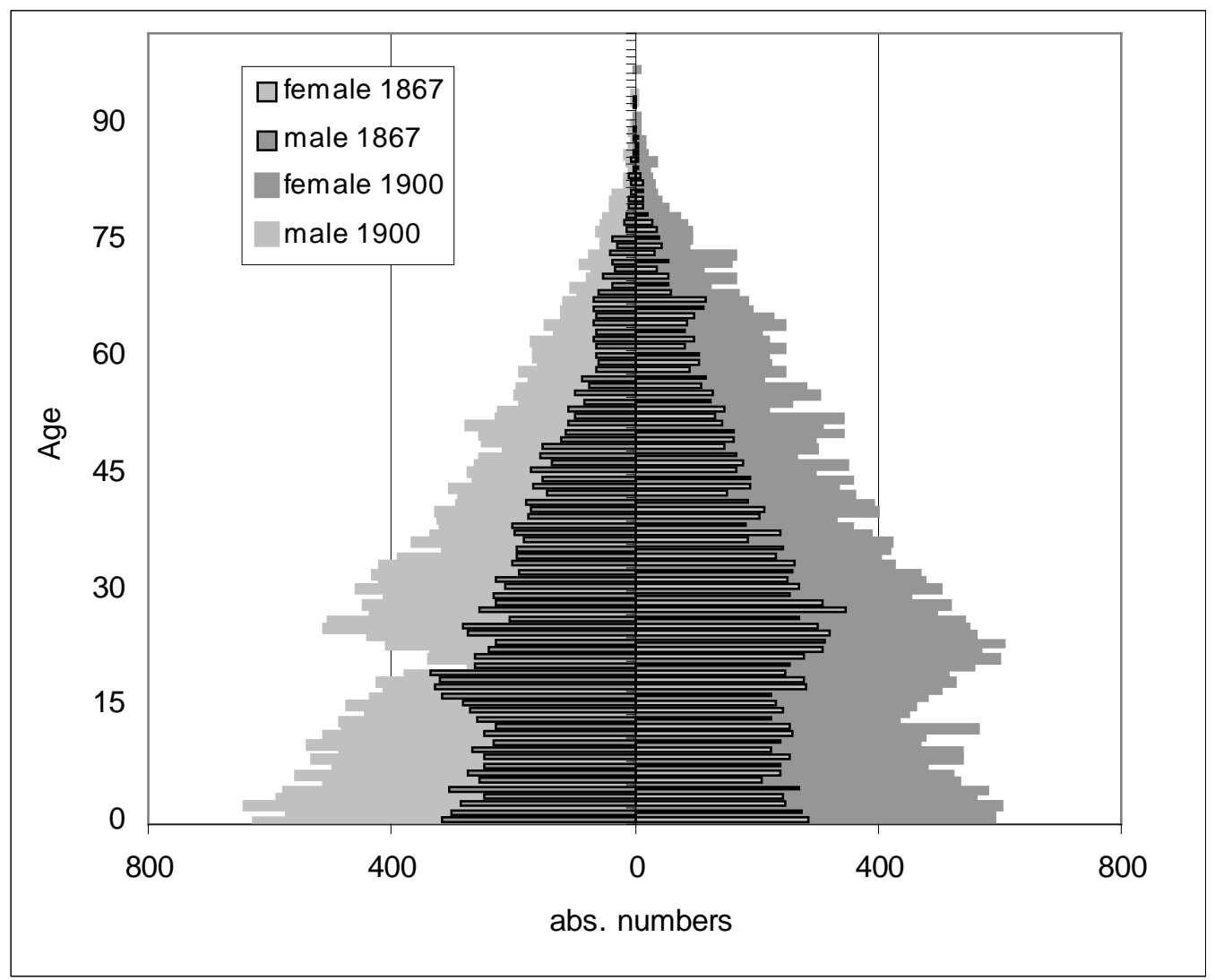

Note: the data for 1900 is weighted population.

Table 1: occupational structure in Rostock: men aged 15 and more by occupation and census year*

\begin{tabular}{|l|r|r|r|r|}
\hline \multicolumn{1}{|c|}{ Occupational category } & 1867 & \multicolumn{3}{c|}{1900} \\
\hline professional and technical jobs & & Born in Rostock & Born outside & overall \\
\hline administrative and managerial jobs & 6.5 & 7.5 & 9.6 & 9.0 \\
\hline clerical jobs & 1.1 & 1.3 & 1.8 & 1.7 \\
\hline trade & 2.2 & 4.3 & 5.0 & 4.8 \\
\hline service & 7.0 & 10.5 & 8.1 & 8.8 \\
\hline agriculture & 3.4 & 5.2 & 6.1 & 5.8 \\
\hline production and transport & 4.5 & 3.8 & 1.7 & 2.3 \\
\hline Unskilled workers & 39.1 & 41.9 & 34.5 & 36.5 \\
\hline missing & 18.4 & 13.5 & 24.6 & 21.6 \\
\hline $\mathrm{N}=$ & 17.8 & 12.0 & 8.5 & 9.4 \\
\hline
\end{tabular}

* Occupational structure in Rostock can be assessed comprehensively for male population only (men aged 15 and more). Two thirds of women in this age group have no occupation stated in the censuses and therefore cannot be dealt with here. Underregistration of female occupations affected particularly married and widowed women. All occupations were coded into the HISCO-scheme (van Leeuwen, Maas, Miles 2002). The data for 1900 is only a 46-percent sample. Also, all males with occupational terms referring to workers without any further specification were put into a separate category (unskilled workers). 
Figure 2: Proportions ever-married in Rostock by census year
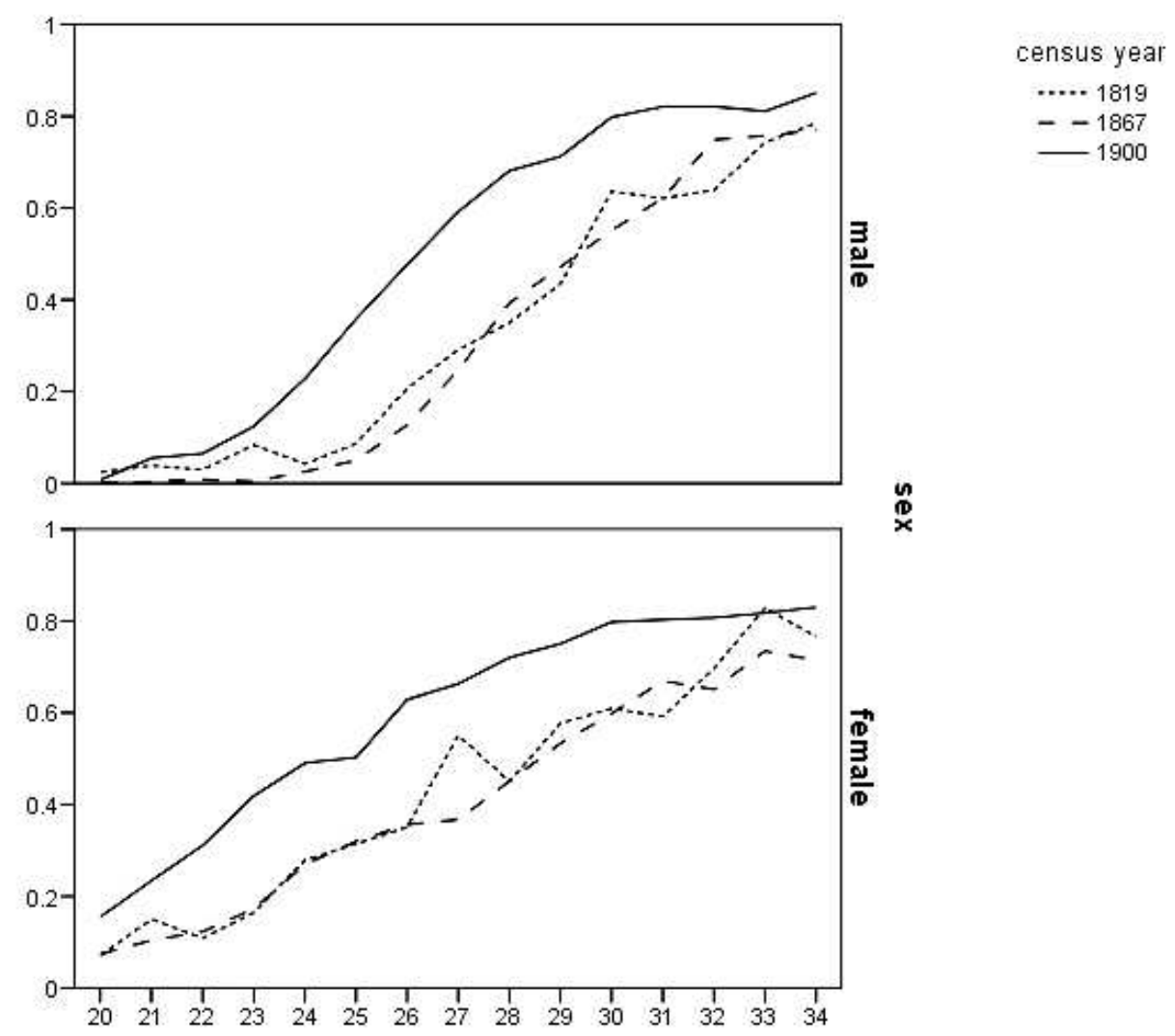

$\underset{1}{\infty}$

Note: the data for 1900 is weighted population. 


\section{Figure 3: Proportions ever-married by census year and occupational sectors (males}

only)*
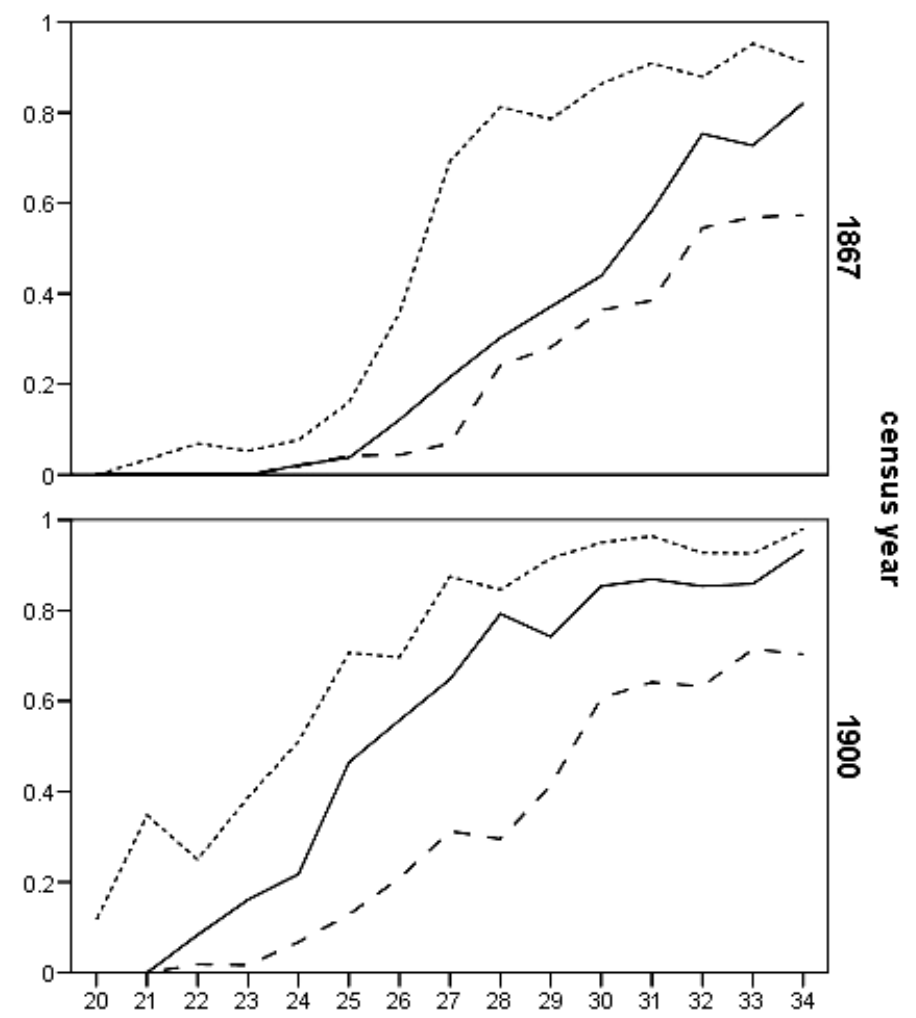

socio-economic group

- skilled worker

..... unskilled worker

- - others

察

ตั

* The major groups of the HISCO codes were merged here into only three groups (some groups are rather small and yield therefore unreliable results; some groups display a rather similar pattern in age at marriage). The three major groups are: unskilled workers (workers without any further specification), skilled workers (service, agriculture, production and transport), and others (professional and technical jobs, administrative and managerial jobs, clerical jobs, trade, missing). 
Figure 4: Living with at least one parent in Rostock by sex and census year
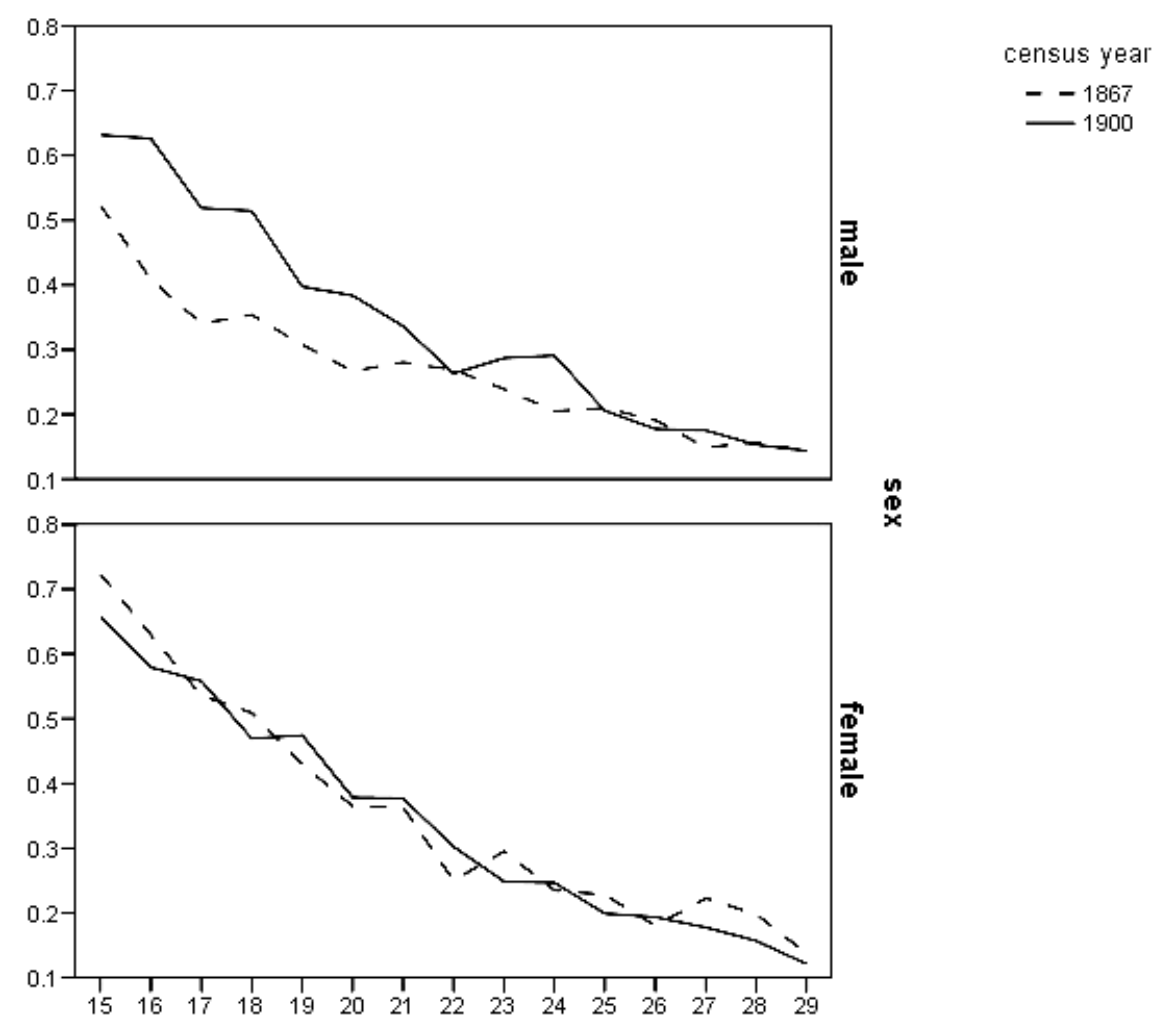

$\stackrel{\text { ก }}{\times}$

Note: the data for 1900 is weighted population.

Figure 5: Household relationship patterns of male unskilled workers by census year

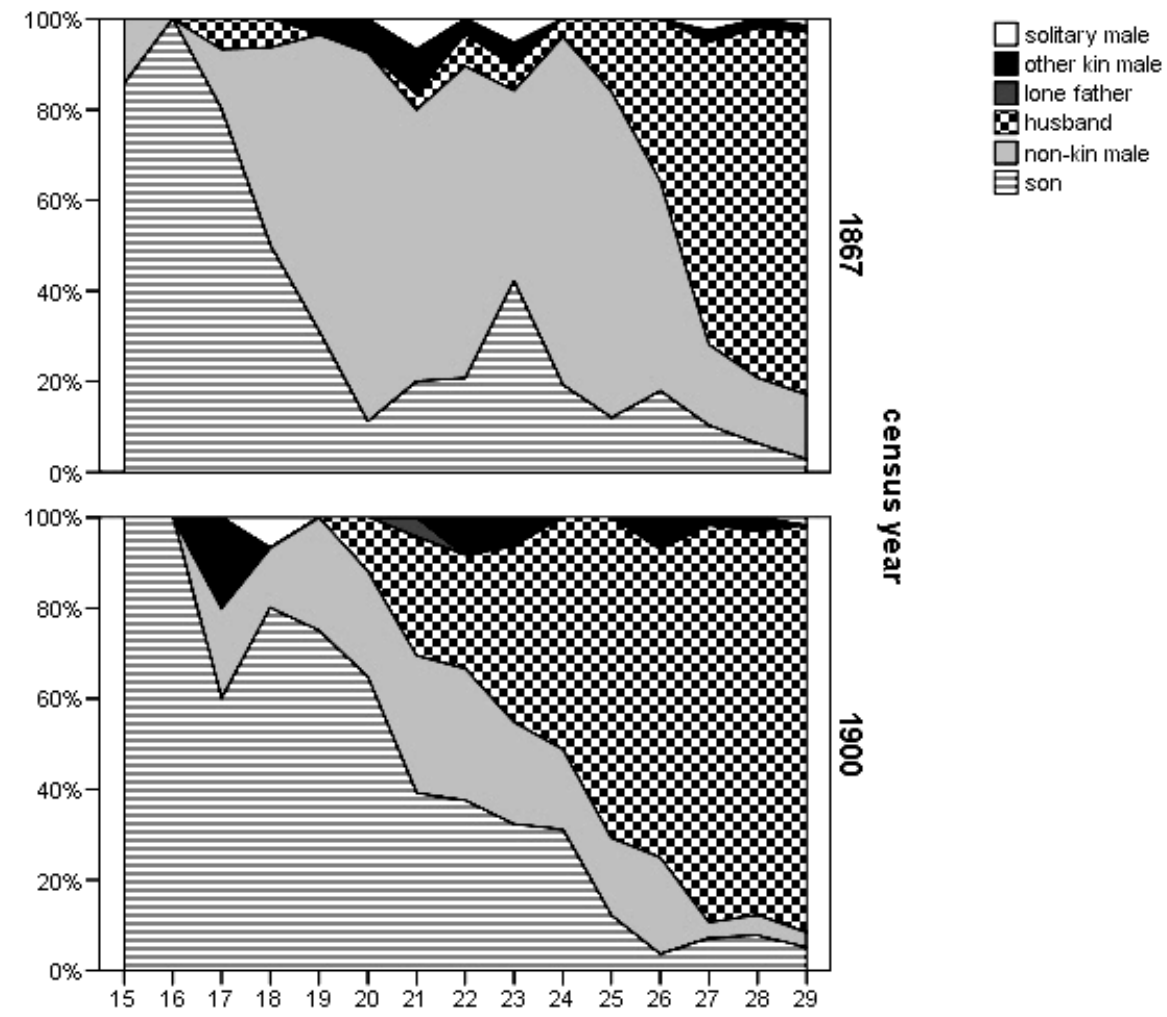


Table 2: Entry into marriage and into headship by census year, occupational sector, district and migration status (males only)

\begin{tabular}{|c|c|c|c|}
\hline & SMAM & SMAHF & $\begin{array}{l}\text { Absolute } \\
\text { difference }\end{array}$ \\
\hline $\begin{array}{l}\text { Type of } \\
\text { characteristic }\end{array}$ & \multicolumn{3}{|c|}{1867} \\
\hline Altstadt & 30,2 & 29,1 & $-1,1$ \\
\hline Neustadt & 30,4 & 29,7 & $-0,7$ \\
\hline STV & 30,1 & 29,0 & $-1,1$ \\
\hline KTV & 29,7 & 29,5 & $-0,2$ \\
\hline skilled workers & 31,5 & 31,3 & $-0,2$ \\
\hline unskilled workers & 26,8 & 26,5 & $-0,3$ \\
\hline others & 31,4 & 28,9 & $-2,5$ \\
\hline overall & 30,3 & 29,4 & $-0,9$ \\
\hline $\begin{array}{l}\text { Type of } \\
\text { characteristic }\end{array}$ & \multicolumn{3}{|c|}{1900} \\
\hline Altstadt & 27,6 & 26,8 & $-0,8$ \\
\hline Neustadt & 28,5 & 27,9 & $-0,6$ \\
\hline STV & 29,7 & 29,1 & $-0,6$ \\
\hline KTV & 26,3 & 26,1 & $-0,2$ \\
\hline skilled workers & 26,7 & 26,2 & $-0,5$ \\
\hline unskilled workers & 24,4 & 23,9 & $-0,5$ \\
\hline others & 30,2 & 30,0 & $-0,2$ \\
\hline born in Rostock & 28,4 & 28,2 & $-0,2$ \\
\hline born outside & 27,1 & 26,7 & $-0,4$ \\
\hline overall & 27,4 & 27,0 & $-0,4$ \\
\hline
\end{tabular}

Note: the data for 1900 is weighted population.

Table 3: Never married population aged 45-54 years in Rostock by census year

\begin{tabular}{|l|c|c|c|c|}
\hline & 1867 & \multicolumn{3}{|c|}{1900} \\
\hline $\begin{array}{l}\text { Male population by } \\
\text { occupational sector }\end{array}$ & overall & born in Rostock & $\begin{array}{c}\text { born outside } \\
\text { Rostock }\end{array}$ & overall \\
\hline skilled workers & 5,2 & 5,8 & 6,5 & 6,3 \\
\hline unskilled workers & 3,4 & 7,1 & 2,4 & 2,9 \\
\hline others & 22,6 & 16,5 & 12,5 & 13,4 \\
\hline men overall & $\mathbf{9 , 6}$ & 9,3 & 7,2 & $\mathbf{7 , 7}$ \\
\hline women overall & $\mathbf{1 7 , 2}$ & 21,7 & 11,6 & $\mathbf{1 4 , 5}$ \\
\hline
\end{tabular}

Note: the data for 1900 is weighted population. 
Table 4: Household typology according to Hammel-Laslett scheme in Rostock by census year

\begin{tabular}{|c|c|c|c|c|c|c|c|c|c|}
\hline \multirow[b]{2}{*}{ Categories } & \multirow[b]{2}{*}{$\begin{array}{l}\text { Classes } \\
\text { (Laslett) }\end{array}$} & \multicolumn{4}{|c|}{1867} & \multicolumn{4}{|c|}{1900} \\
\hline & & Freq & $\%$ & $\%$ & $\begin{array}{c}\% \text { with } \\
\text { servants }\end{array}$ & Freq & $\%$ & $\%$ & $\begin{array}{c}\% \text { with } \\
\text { servants }\end{array}$ \\
\hline \multirow[b]{2}{*}{ 1. Solitaries } & $1 a$ & 476 & 7,12 & \multirow{2}{*}{17,41} & \multirow{2}{*}{17,63} & 1121 & 7,76 & \multirow{2}{*}{15,27} & \multirow{2}{*}{13,50} \\
\hline & $1 b$ & 688 & 10,29 & & & 1085 & 7,51 & & \\
\hline \multirow[b]{3}{*}{ 2. No family } & $2 a$ & 100 & 1,50 & \multirow{3}{*}{2,77} & \multirow{3}{*}{40,32} & 220 & 1,52 & \multirow{3}{*}{2,69} & \multirow{3}{*}{25,30} \\
\hline & $2 b$ & 85 & 1,27 & & & 168 & 1,16 & & \\
\hline & $2 c$ & 0 & 0,00 & & & 0 & 0,00 & & \\
\hline \multirow{4}{*}{$\begin{array}{l}\text { 3. Simple } \\
\text { family } \\
\text { households }\end{array}$} & $3 a$ & 891 & 13,33 & \multirow{4}{*}{71,41} & \multirow{4}{*}{29,14} & 2089 & 14,46 & \multirow{4}{*}{72,98} & \multirow{4}{*}{14,40} \\
\hline & $3 b$ & 3123 & 46,72 & & & 6744 & 46,67 & & \\
\hline & $3 c$ & 111 & 1,66 & & & 223 & 1,54 & & \\
\hline & $3 d$ & 649 & 9,71 & & & 1489 & 10,30 & & \\
\hline \multirow{4}{*}{$\begin{array}{l}\text { 4. Extended } \\
\text { family } \\
\text { households }\end{array}$} & $4 a$ & 174 & 2,60 & \multirow{4}{*}{8,35} & \multirow{4}{*}{37,61} & 655 & 4,53 & \multirow{4}{*}{8,80} & \multirow{4}{*}{17,60} \\
\hline & $4 b$ & 50 & 0,75 & & & 35 & 0,24 & & \\
\hline & $4 \mathrm{c}$ & 180 & 2,69 & & & 324 & 2,24 & & \\
\hline & $4 d$ & 154 & 2,30 & & & 257 & 1,78 & & \\
\hline \multirow{5}{*}{$\begin{array}{l}\text { 5. Multiple } \\
\text { family } \\
\text { households }\end{array}$} & $5 a$. & 2 & 0,03 & \multirow{5}{*}{0,06} & \multirow{5}{*}{50,00} & 22 & 0,15 & \multirow{5}{*}{0,28} & \multirow{5}{*}{25,00} \\
\hline & $5 b$ & 2 & 0,03 & & & 9 & 0,06 & & \\
\hline & $5 c$ & 0 & 0,00 & & & 1 & 0,01 & & \\
\hline & $5 d$ & 0 & 0,00 & & & 0 & 0,00 & & \\
\hline & $5 e$ & 0 & 0,00 & & & 8 & 0,06 & & \\
\hline \multicolumn{2}{|c|}{ Total hhs } & 6685 & 100.00 & 100,00 & 28,42 & 14450 & 100,00 & 100,00 & 14,90 \\
\hline
\end{tabular}

*Servants include: domestic servants, apprentices, and journeymen.

Note: the data for 1900 is weighted population.

Table 5: Summary characteristics of household composition in Rostock by census years

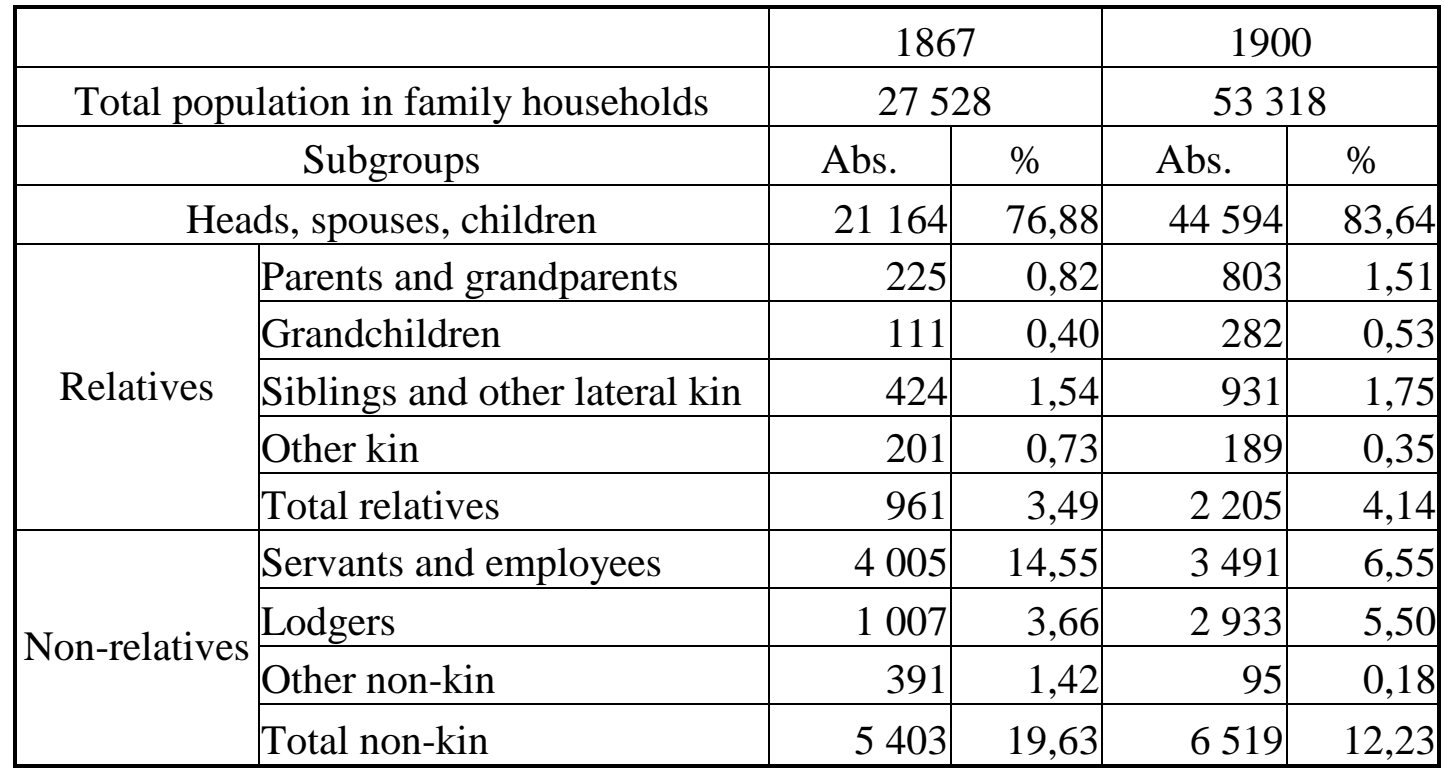

Note: the data for 1900 is weighted population. 
Figure 6: Household type membership by age and census year

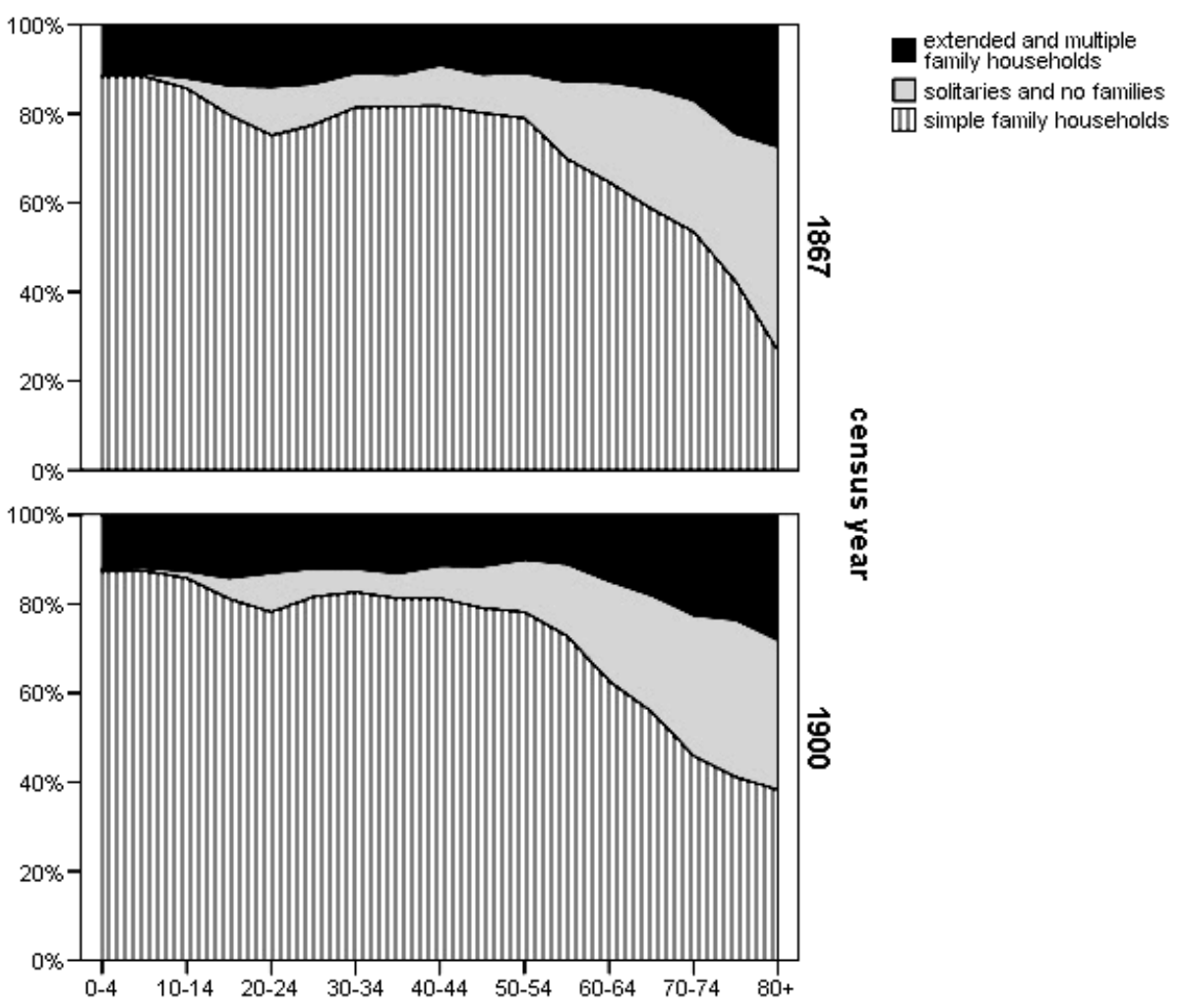

Note: the data for 1900 is weighted population.

Figure 7: Living with at least one child in Rostock by age and census year
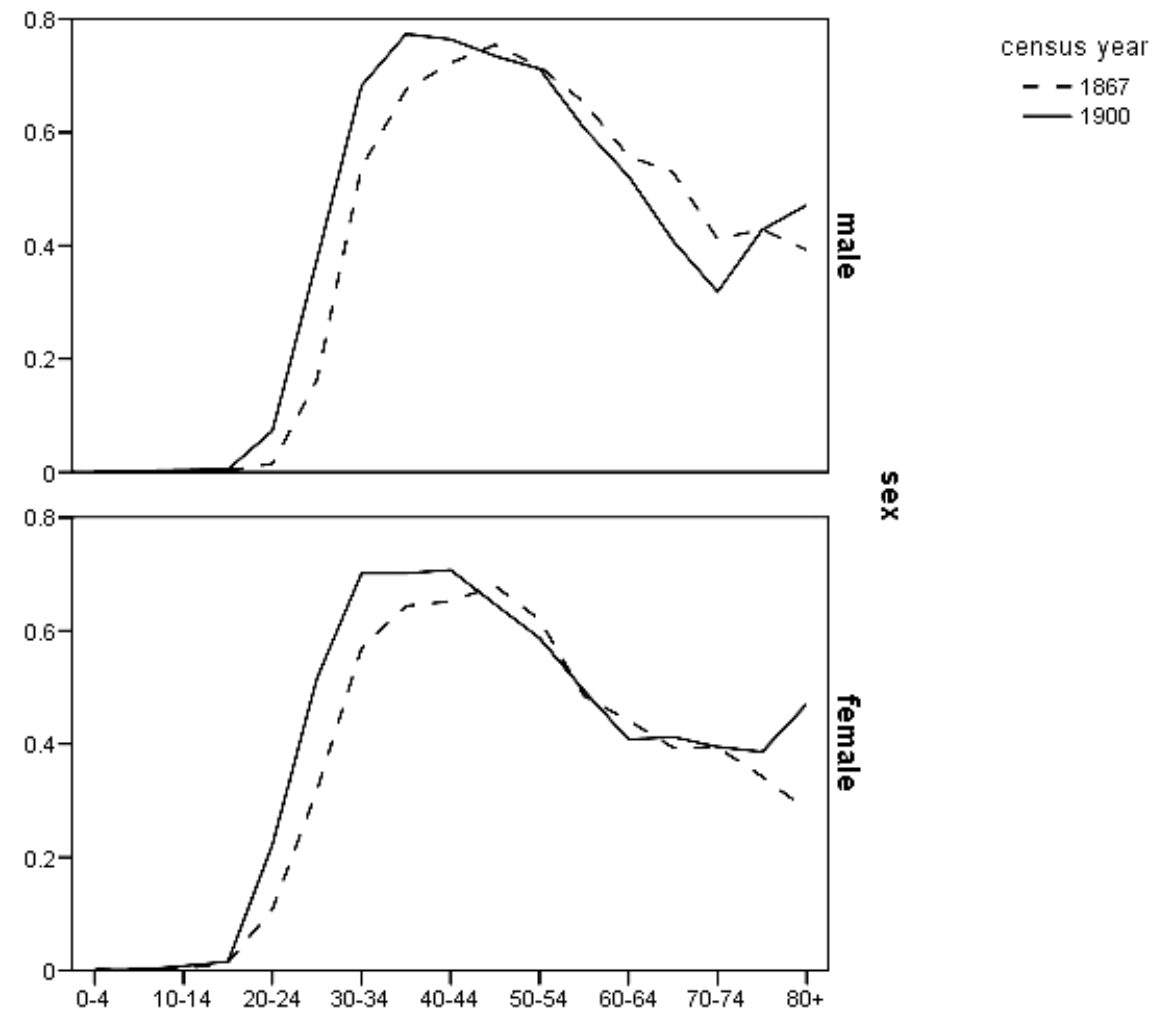

Note: the data for 1900 is weighted population. 
Figure 8: Living with at least one married child in Rostock by age and census year
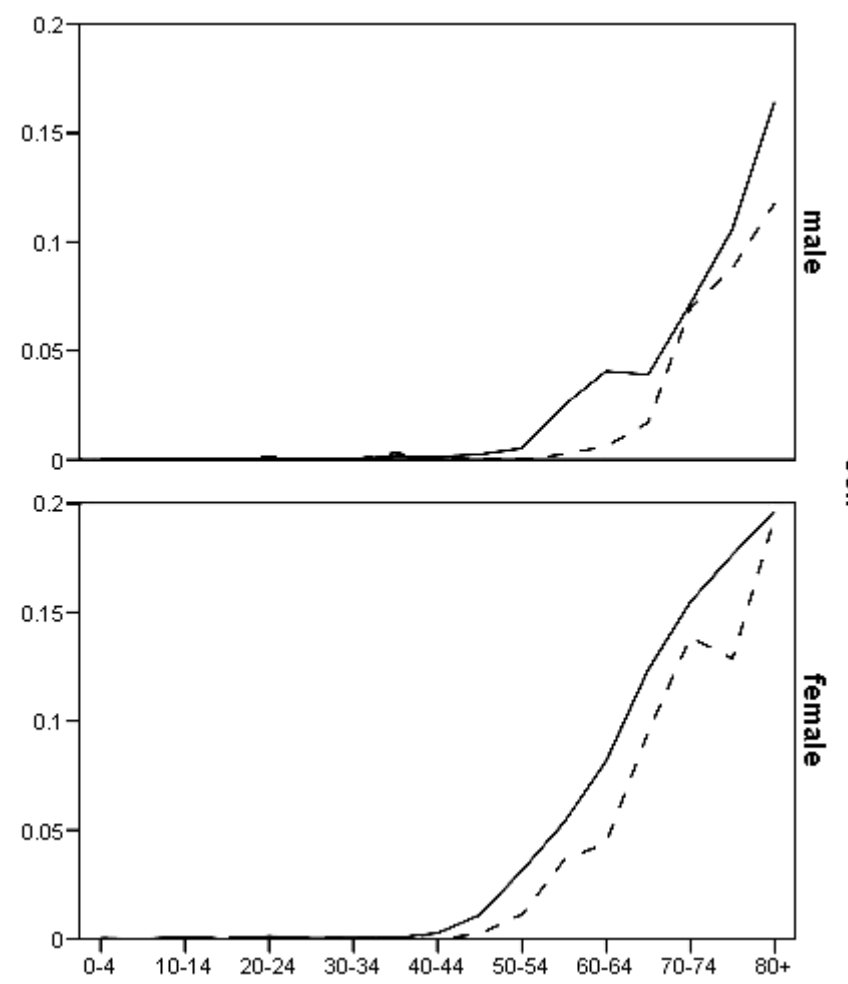

census year

- -1867

1900

Note: the data for 1900 is weighted population.

Figure 9: Living as an unrelated primary and secondary individual in Rostock by age and census year
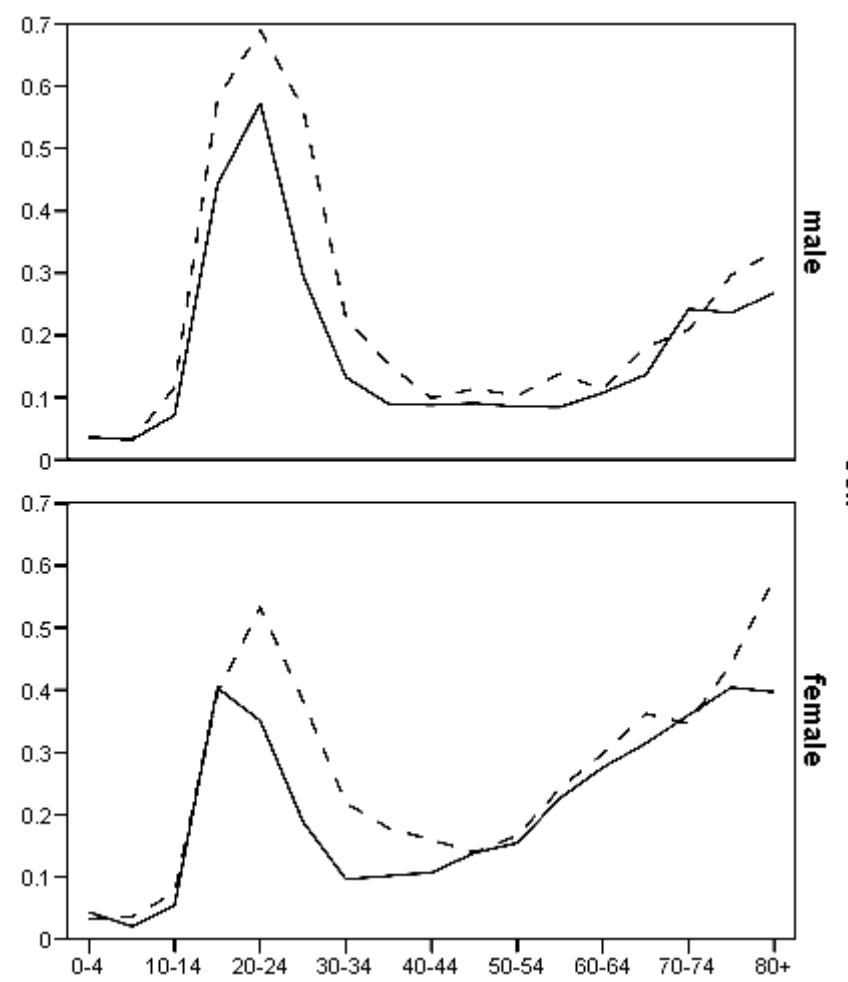

census yea

$-186 \overline{7}$

$-1900$

Note: the data for 1900 is weighted population. 
Figure 10: Household type membership of elderly people (65+) in Rostock by census year

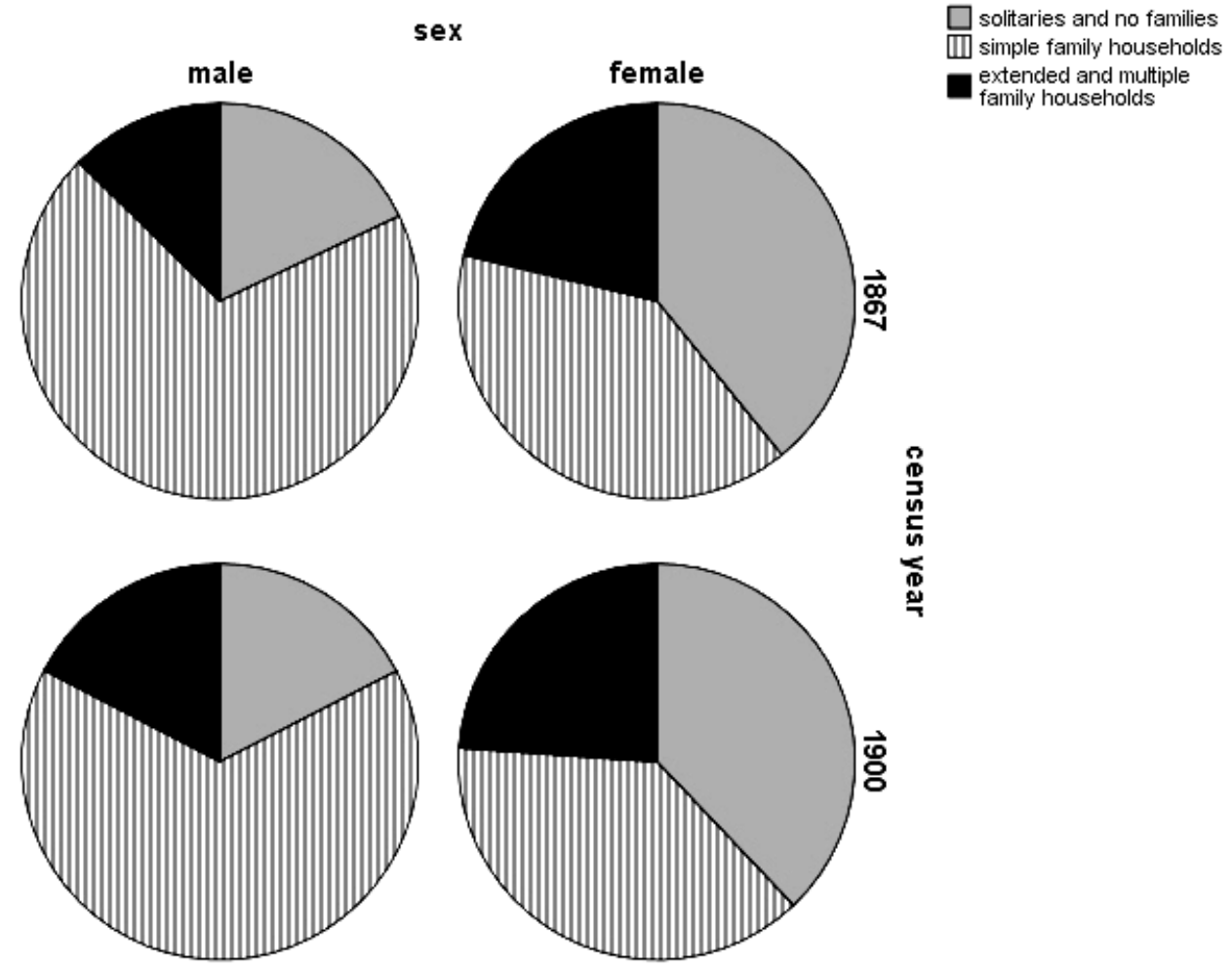

Note: the data for 1900 is weighted population.

Table 6. Residence patterns of the elderly in Rostock by sex, marital status, and type of residential positioning and census year

\begin{tabular}{|l|l|r|r|r|r|r|r|}
\hline \multicolumn{2}{|c|}{} & \multicolumn{2}{|c|}{$\begin{array}{c}\text { Having no co- } \\
\text { resident relatives of } \\
\text { any kind }\end{array}$} & $\begin{array}{c}\text { Having at least one } \\
\text { person from the pool } \\
\text { of immediate kin }\end{array}$ & \multicolumn{2}{|c|}{$\begin{array}{c}\text { Living in an empty } \\
\text { nest }\end{array}$} \\
\hline \multirow{3}{*}{ Gender } & $\begin{array}{l}\text { Marital } \\
\text { status }\end{array}$ & 1867 & 1900 & 1867 & 1900 & 1867 & 1900 \\
\hline \multirow{4}{*}{ Men } & unmarried & 76.7 & 61.7 & 6.7 & 9.2 & 16.7 & 30.0 \\
\cline { 2 - 8 } & married & 1.5 & 2.8 & 98.2 & 96.5 & 44.9 & 57.4 \\
\cline { 2 - 8 } & widowed & 49.4 & 44.4 & 44.6 & 49.1 & 6.0 & 6.6 \\
\cline { 2 - 8 } & overall & 21.9 & 19.6 & 74.7 & 75.5 & 31.8 & 41.0 \\
\hline \multirow{4}{*}{ Women } & unmarried & 62.4 & 58.4 & 10.7 & 8.6 & 27.0 & 33.0 \\
\cline { 2 - 8 } & married & 2.1 & 2.2 & 97.9 & 97.3 & 59.6 & 60.1 \\
\cline { 2 - 8 } & widowed & 43.6 & 40.1 & 46.3 & 50.5 & 10.1 & 9.2 \\
\cline { 2 - 8 } & overall & 38.4 & 34.7 & 50.4 & 54.1 & 24.1 & 24.4 \\
\hline
\end{tabular}

Data for men: 623 individuals in 1867 and 955 in 1900

Data for women: 901 individuals in 1867 and 1,689 in 1900 